VALÉRIA GOMES DA SILVA

AVALIAÇÃo dA POSSíVEL ASSOCIAÇÃO DE LESÃO DE CÉLULAS CILIADAS EXTERNAS COCLEARES COM A EXPOSIÇÃO À MÚSICA AMPLIFICADA EM ADOLESCENTES 


\author{
UNIVERSIDADE DE BRASÍLIA \\ FACULDADE DE MEDICINA \\ PROGRAMA DE PÓS-GRADUAÇÃO EM CIÊNCIAS MÉDICAS
}

VALÉRIA GOMES DA SILVA

\title{
AVALIAÇÃO DA POSSÍVEL ASSOCIAÇÃO DE LESÃO DE CÉLULAS CILIADAS EXTERNAS COCLEARES COM A EXPOSIÇÃO À MÚSICA AMPLIFICADA EM ADOLESCENTES
}

Tese apresentada como requisito parcial para a obtenção do Título de Doutora em Ciências Médicas pelo Programa de PósGraduação em Ciências Médicas da Universidade de Brasília.

Orientador: Prof. Dr. Carlos Augusto Costa Pires de Oliveira Co-orientadora: Profa. Dra. Isabella Monteiro de Castro Silva

BRASÍLIA 
VALÉRIA GOMES DA SILVA

AVALIAÇÃO DA POSSÍVEL ASSOCIAÇÃO DE LESÃO DE CÉLULAS CILIADAS EXTERNAS COCLEARES COM A EXPOSIÇÃO À MÚSICA AMPLIFICADA EM ADOLESCENTES

Aprovada em 10/02/2017. 


\section{Ficha catalográfica}

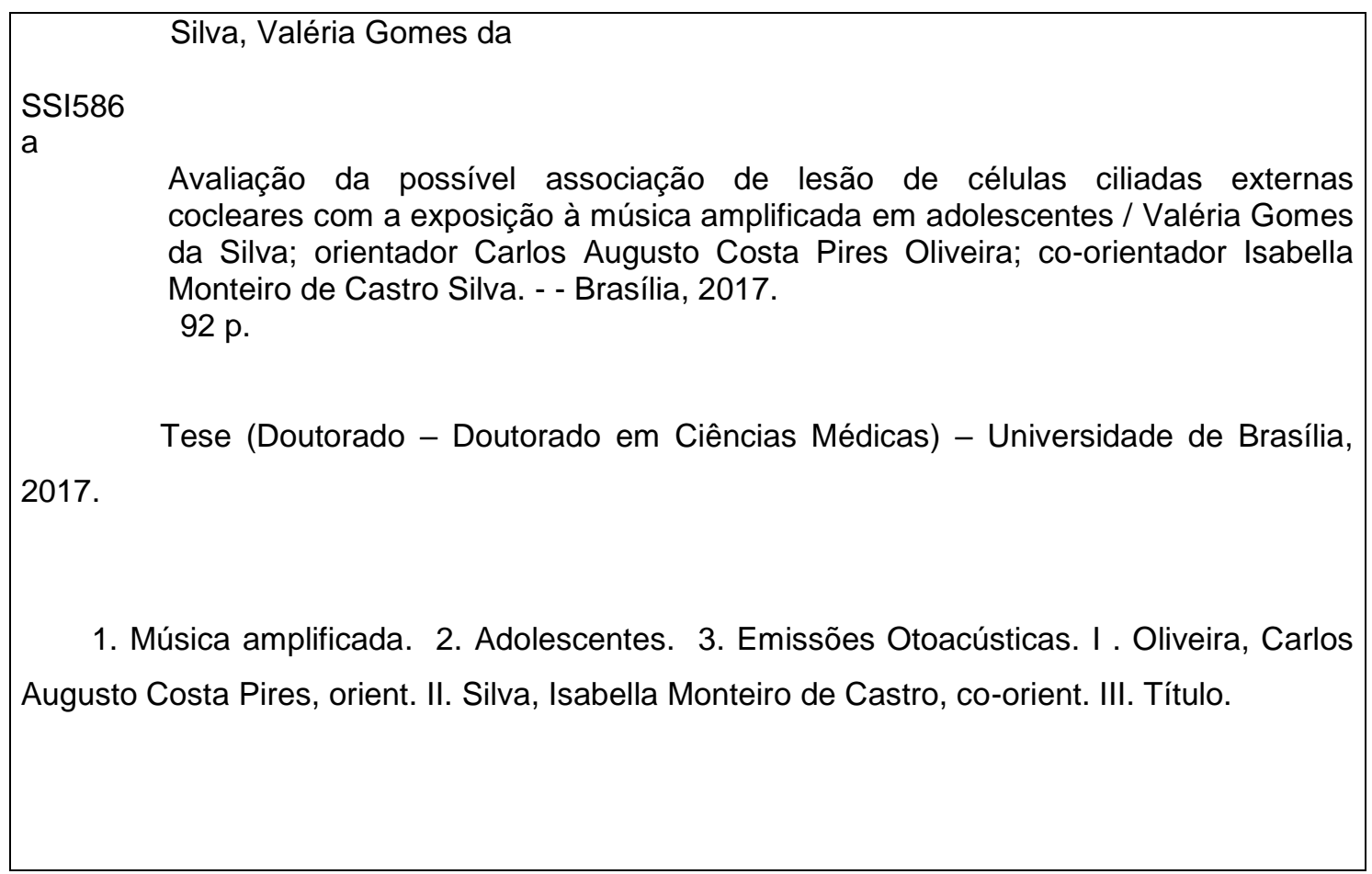




\section{BANCA EXAMINADORA}

$1^{\circ}$ Membro (Presidente) Professor Dr. Carlos Augusto Costa Pires de Oliveira Universidade de Brasília

$2^{\circ}$ Membro: Professor Dr. André Luiz Lopes Sampaio Universidade de Brasília

$3^{\circ}$ Membro: Professor Dr. Pedro Luiz Tauil Universidade de Brasília

$4^{\circ}$ Membro: Professora Dra. Marlene Escher Boger

Centro Universitário Planalto do Distrito Federal

5Nembro: Dra. Vanessa Furtado de Almeida

Pesquisadora colaboradora do Programa de Pós-Graduação em Ciências da Saúde

Suplente: Professora Dra. Monique Antunes de Souza Chelminski Barreto Centro Universitário Planalto do Distrito Federal Hospital Materno Infantil de Brasília 
Aos meus pais, Santos e Djanira que são os alicerces de minha vida e por se fazerem presentes em todos os momentos não me deixando desistir. A firmeza e determinação que tive, vieram de vocês! $A$ eles devo a pessoa que me tornei, e sou feliz e orgulhosa por chamá-los de pai e mãe. 


\section{AGRADECIMENTOS}

A Deus, meu refúgio e fortaleza, pelas imerecidas bênçãos e por ter me guiado até aqui, dando-me forças para superar todos os obstáculos neste período.

Ao Prof. Dr. Carlos Augusto, pela credibilidade e oportunidade de realizar este trabalho com sua parceria. Por ter sido tão cordial e contribuído de maneira substancial neste estudo.

Ao Dr. André Sampaio, por suas orientações ao logo destes anos e ter apostado no meu esforço e capacidade.

À Dra. Isabella Monteiro pelas sábias orientações, pela paciência, compreensão e por compartilhar suas experiências. Suas contribuições foram essenciais para este estudo.

À amiga Gláucia Magalhães, por ter sido uma verdadeira companheira de trabalho, pela fidelidade e compromisso. A você, eu devo parte deste trabalho, pois sem sua ajuda, não teria conseguido tudo que havia planejado.

Às amigas Ada Urdapileta, Marlene Escher e Monique Barreto, pelo auxílio naquelas horas difíceis, compartilhando sempre suas experiências em elaboração de trabalho científico.

Ao amigo Hugo Aless, que nunca mediu esforços em me ajudar, com seus conhecimentos, em tempo hábil.

Ao casal de amigos Lívea Helena e João Júnior, que com muita presteza contribuíram com minha coleta de dados.

Aos meus irmãos, Cléia e Cléber, pelo amor e carinho, incentivo e, em especial a você minha querida irmã Cléia, por nunca ter me deixado desistir de meus sonhos e pelas buscas incessantes de soluções para minhas dificuldades.

Aos diretores, coordenadores e professores das escolas por aceitarem a realização deste estudo e pelo acolhimento durante todo o período da coleta de dados.

Aos alunos, que voluntariamente aceitaram participar desta pesquisa e, assim, contribuíram para realização deste estudo.

A todos que direta ou indiretamente participaram da concretização deste ideal. A todos vocês, meu carinho e eterno agradecimento! 


\section{RESUMO}

Introdução: Os adolescentes têm apresentado sinais de comprometimento coclear precocemente e o hábito de se expor à música de forte intensidade pode estar diretamente envolvido com esses achados. A audiometria tonal limiar tem se mostrado insuficiente para determinar o estado funcional das células ciliadas externas (CCE). Uma vez que o exame de emissões otoacústicas demonstra o status do funcionamento destas células, ele vem sendo adotado como procedimento de investigação auditiva em sujeitos expostos a altos níveis de intensidade. Objetivo: Verificar a associação das alterações das células ciliadas externas com a exposição à música amplificada em uma amostra de estudantes do ensino médio. Material e Método: Estudo retrospectivo do tipo caso-controle. A amostra foi composta por adolescentes com faixa etária entre 13 e 18 anos. Os critérios de exclusão foram a presença de: histórico de problemas de orelha externa e média; resultados de audiometria acima de 25dBNA em qualquer uma das frequências avaliadas; ausência de reflexos acústicos em todas as frequências e curvas timpanométricas tipo " $B$ " ou " $C$ ". Foram realizados os testes de audiometria, imitanciometria e emissões otoacústicas por estímulo produto de distorção em 90 indivíduos, selecionando-se 60 para o estudo caso-controle. Em seguida, os sujeitos foram investigados a respeito dos hábitos auditivos e classificados como expostos e não expostos. Resultados: No estudo casocontrole, composto por 30 casos e 30 controles, $75 \%$ foram considerados expostos e $25 \%$ não expostos. Aqueles que estão expostos possuem 9.33 vezes mais chance de terem alterações nas células ciliadas externas em relação àqueles que não estão expostos. Discussão: $\mathrm{Na}$ comparação dos dois subgrupos, exposto e não exposto, observaram-se melhores respostas das amplitudes na orelha direita, principalmente no subgrupo dos não expostos, que tiveram maiores amplitudes. Os resultados encontrados entre os grupos estudados não foram estatisticamente significantes em todas as frequências avaliadas, contudo elas sinalizam, em maior ou menor grau, um prognóstico de suscetibilidade para perdas auditivas. Conclusão: As alterações de células ciliadas externas encontradas na amostra de estudantes do Distrito Federal estão associadas à exposição à música amplificada. Os participantes com alterações nos exames das emissões otoacústicas foram significativamente mais expostos à música amplificada.

PALAVRAS-CHAVES: Adolescentes, música amplificada, emissões otoacústicas. 


\section{ABSTRACT}

Adolescents have shown signs of early cochlear involvement and the habit of exposing themselves to loud music may be directly involved with these findings. Tonal audiometry thresholds have been shown to be insufficient to determine the functional status of outer hair cells (SCC). Since otoacoustic emission testing demonstrates the functioning status of these cells, it has been adopted as an auditory investigation procedure, including the monitoring of the hearing of subjects exposed to high levels of intensity, allowing identification of changes in individuals without audiometric hearing loss. Objective: To verify the association of external hair cell changes with exposure to amplified music in a sample of high school students. Material and Method: Retrospective case-control study. The sample consisted of adolescents aged between 13 and 18 years. The exclusion criteria were histories of external and middle ear problems; Present audiometry results above 25dBNA in any of the frequencies evaluated; Absence of acoustic reflexes at all frequencies and "B" or " $\mathrm{C}$ " tympanometric curves. The audiometry, immitance and otoacoustic emissions tests were performed by distortion product in 90 individuals, selecting 60 for the case-control study. The subjects were then investigated regarding auditory habits and classified as exposed and not exposed. RESULTS: In the case-control study, composed of 30 cases and 30 controls, $75 \%$ were considered exposed and $25 \%$ were not exposed. Those who are exposed are 9.33 times more likely to have changes in outer hair cells compared to those who are not exposed. Discussion: In the comparison of the two subgroups, exposed and not exposed, we observed dominance of better amplitudes responses in the right ear, especially in the subgroup of the nonexposed, which had even better responses. The results found among the studied groups were not statistically significant in all the evaluated frequencies, however they indicate, to a greater or lesser degree, a prognosis of susceptibility to hearing loss. Conclusion: The alterations of external hair cells found in the sample of students of the Federal District are associated with exposure to amplified music. Participants with abnormal otoacoustic emissions were significantly more exposed to amplified music.

KEYWORDS: Adolescents, amplified music, otoacoustic emissions. 


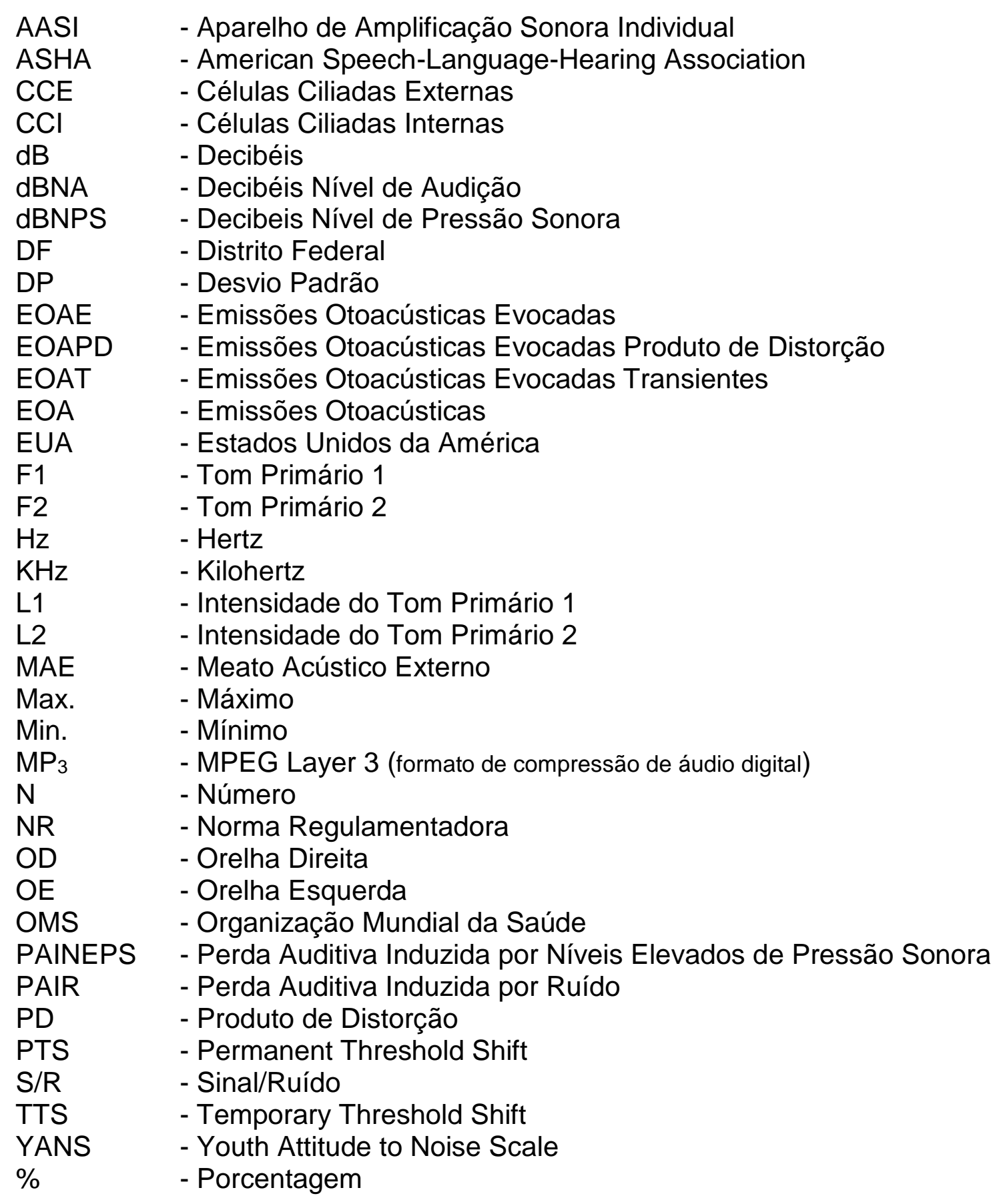




\section{LISTA DE FIGURAS}

Figura 1 - Ouvido humano

Figura 2 - Células cocleares

Figura 3 - Modelo de descrição de resultados do exame de EOAPD "Falha"

Figura 4 - Organograma de formação dos grupos da pesquisa e delineamento do estudo.

Figura 5 - Distribuição dos participantes segundo gênero

Figura 6 - Distribuição de idade apresentada pelos participantes

Figura 7 - Resultado do Exame de EOA dos Participantes por Orelha

Figura 8 - Gênero dos Participantes do Estudo segundo Grupo

Figura 9 - Distribuição percentual das idades dos participantes segundo grupo

Figura 10 - Distribuição do gênero dos participantes quanto à exposição ao risco

Figura 11 - Boxplot da idade dos participantes segundo exposição ao risco

Figura 12 - Comparativo de respostas da amplitude da orelha esquerda por grupos distintos exposto caso e não exposto controle

Figura 13 - Comparativo de respostas da relação $S / R$ da orelha esquerda por grupos distintos exposto caso e não exposto controle

Figura 14 - Comparativo de respostas da amplitude da orelha direita por grupos distintos exposto caso e não exposto controle

Figura 15 - Comparativo de respostas da relação $S / R$ da orelha direita por grupos distintos exposto caso e não exposto controle 


\section{LISTA DE TABELAS}

Tabela 1 - Média das amplitudes e relação sinal/ruído para os grupos caso e controle em relação ao exposto e não exposto da orelha esquerda

Tabela 2 - Média das amplitudes e relação sinal/ruído para os grupos caso e controle e relação ao exposto e não exposto da orelha direita

Tabela 3 - Contingência entre os grupos e subgrupos propostos 
1 - INTRODUÇÃO 15

2 - OBJETIVOS 17

2.1 Objetivo Geral. 17

2.2 Objetivo Específico 17

3 REVISÃO DE LITERATURA 18

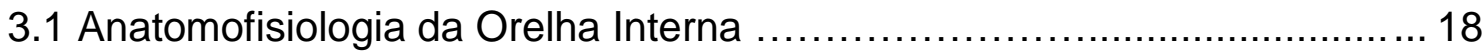

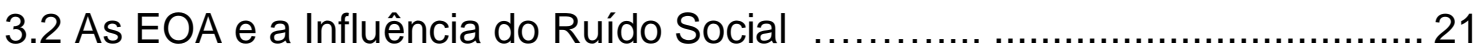

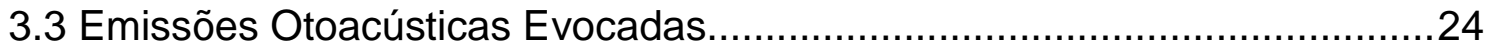

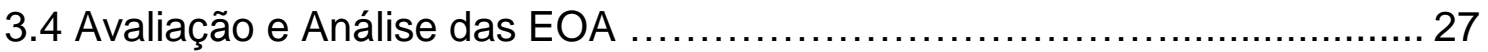

3.5 O Papel das EOA no Diagnóstico das Alterações Auditivas....................... 29

3.6 Adolescentes e sua Relação com a Música Amplificada.............................30

4 - MÉTODO

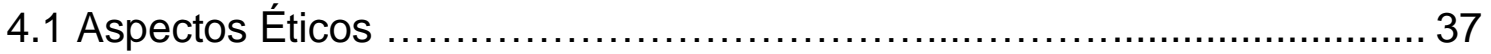

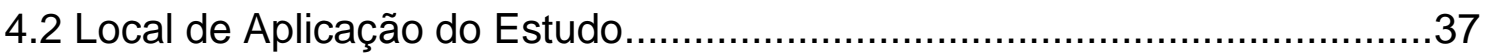

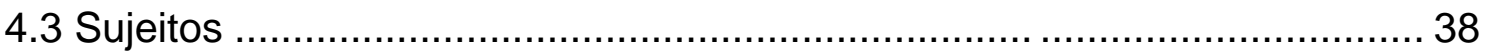

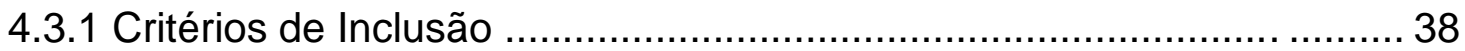

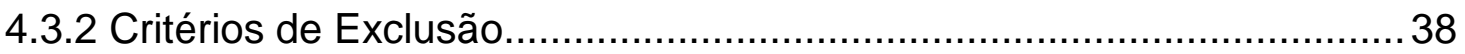

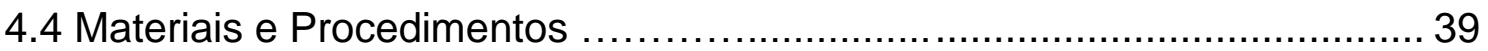

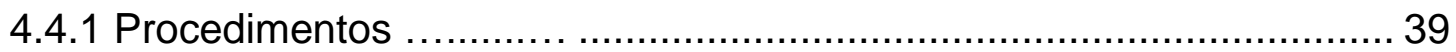

4.5 Avaliação da Audição e Critérios para a Análise dos Exames.................... 40

4.6 Definição da Amostra ....................................................................... 42

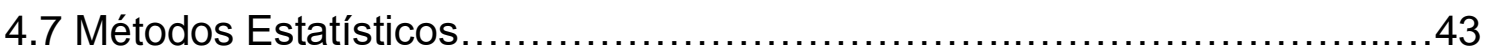

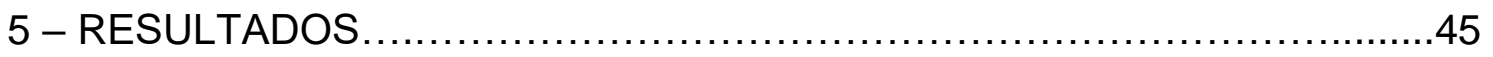

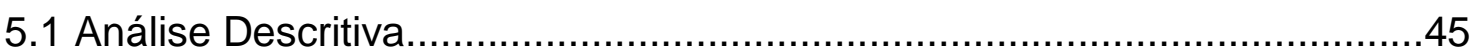

5.2 Análise das Correlações - Caso-Controle......................................... 47

5.3 Exposição ao Risco - Exposto e Não-Exposto.......................................... 49

5.4 Análise de Associação - Razão de Chances........................................... 56 
6 - DISCUSSÃO 57

6.1 Estudo das Emissões Otoacústicas Produto de Distorção......................... 57

6.2 Análise dos Resultados das EOAPD ................................................... 58

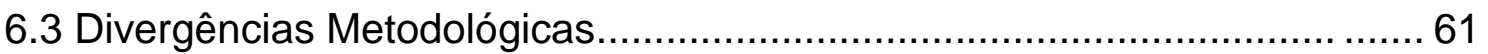

6.4 Exposição dos Jovens à Música Amplificada.......................................... 61

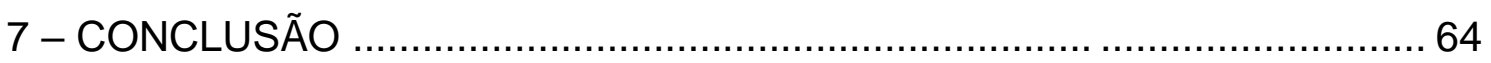

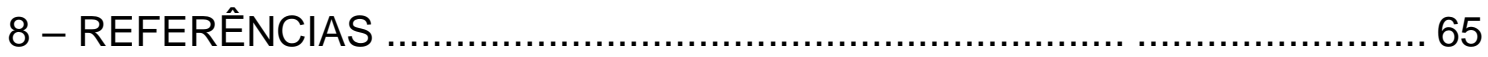

ANEXOS

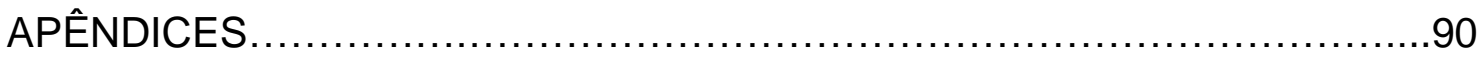




\section{INTRODUÇÃO}

A preocupação com problemas auditivos provocados por exposição ao ruído entre jovens adultos tem crescido cada vez mais, fato que é percebido pelo aumento dos estudos abordando este assunto ${ }^{1-6}$. A perda auditiva induzida por ruído (PAIR) é a segunda causa mais comum de hipoacusia neurossensorial e considerada uma doença crônica irreversível, que lesa as células ciliadas da orelha interna.

Os jovens, na sua maioria adolescentes, estão cada vez mais expostos à música de forte intensidade, especialmente nas suas atividades de lazer como shows musicais que podem alcançar de 100 a $115 \mathrm{~dB}$, sons automobilísticos, cuja intensidade foi mensurada em até $154,7 \mathrm{~dB}$ e também utilizam aparelhos portáteis de música, como MP3 players 3,6,7,8,9,10. A Academia Americana de Fala, Linguagem e Audição - American Speech-Language-Hearing Association (ASHA)- afirma que estes aparelhos de música alcançam intensidades de até $125 \mathrm{~dB}$ (decibéis), dependendo da marca e tipo de fone ${ }^{11}$. Fazem parte ainda da rotina desses jovens, frequentar festas, bares e boates, onde a intensidade sonora varia. No Brasil e EUA, este tipo de estímulo pode alcançar de 93 a 109,7 $\mathrm{dB}$ e, em países como a França e a Argentina, as intensidades são ainda maiores, de 104 a $112 \mathrm{~dB}$. O aparelho auditivo humano é capaz de suportar sons de até 85 dB NPS (níveis de pressão sonora), devido ao mecanismo de defesa. Porém, os que excedem essa intensidade podem causar lesão às células do ouvido. Já os que se aproximam de 130dB NPS podem causar lesões severas ao aparelho auditivo ${ }^{12,13,14,15}$.

As emissões otoacústicas evocadas (EOA), por serem mais sensíveis à exposição ao ruído, permitem a detecção precoce de alterações cocleares, antes mesmo de serem observadas pela audiometria tonal. Elas possibilitam uma avaliação específica da funcionalidade das células ciliadas externas ${ }^{16,17}$. A legislação ${ }^{18}$ reconheceu que as alterações cocleares provocadas pela exposição ao ruído atingem, no início, especificamente a faixa das frequências altas. Dessa forma, um teste auditivo que possibilita a investigação da integridade tonotópica coclear, abrangendo as altas frequências, tem relevância no monitoramento 
ocupacional. Por isso, as emissões otoacústicas por produto de distorção (EOAPD) são o tipo de teste de EOA mais utilizado em pesquisas relacionadas à exposição ao ruído 6,19-23.

Os prejuízos da audição de jovens e a associação com hábitos auditivos com intensidade excessiva são bem documentados, principalmente para a faixa etária a partir de $18 \operatorname{anos}^{1-6,8,9}$. No último estudo feito por nosso grupo, Silva et.al $(2012)^{3}$, a prevalência de lesão das células sensoriais em uma amostra de 134, estudantes de Brasília, com faixa etária entre 13 e 18 anos, utilizando os testes de emissões otoacústicas, foi de 79,9\%. Quanto ao histórico de exposição à música amplificada, 94,0\% relataram usar fones de ouvido e $82,8 \%$ disseram frequentar lugares com música amplificada ${ }^{3}$.

Os resultados encontrados neste estudo ${ }^{3}$ apontaram para a alta prevalência de alterações das células ciliadas externas em jovens do ensino médio. A associação deste prejuízo com hábitos auditivos, reconhecidamente ainda precisa de maiores evidências, o que motivou os autores a continuar investigando a eventual associação de alterações auditivas cocleares com a exposição ao ruído da música amplificada, sendo este o objetivo do presente trabalho. 


\section{OBJETIVOS}

\subsection{Objetivo Geral}

Avaliar eventual existência da associação de alterações das células ciliadas externas com a exposição à música amplificada em uma amostra de estudantes do Distrito Federal.

\subsection{Objetivos Específicos}

- Pesquisar a acuidade auditiva por meio do exame de audiometria tonal;

- Avaliar as condições da orelha média por meio do exame de imitanciometria;

- Investigar a função coclear por meio do exame de emissões otoacústicas produto de distorção EOAPD.

- Analisar a amplitude do sinal e a relação Sinal/Ruído por orelha e frequência.

- Verificar a associação das alterações das células ciliadas externas com o uso de fone de ouvido e/ou exposição à música amplificada entre sujeitos exposto e não exposto. 


\section{REVISÃO DE LITERATURA}

Para uma leitura mais dinâmica do trabalho, os assuntos foram distribuídos em capítulos. Os aspectos fundamentais para compreensão do estudo como anatomofisiologia do órgão da audição e emissões otoacústicas evocadas, estão apresentados nos primeiros subtítulos. A análise da relação sinal/ruído das emissões otoacústicas, o ruído e os hábitos auditivos dos jovens apresentam-se em seguida, já que foram os principais objetos da pesquisa.

\subsection{Anatomofisiologia da Orelha Interna}

O ouvido é o órgão capaz de reconhecer o som emitido pelo ambiente e traduzir essa informação para o cérebro. Ele se divide em três partes: orelha externa, média e interna. Devido ao foco de estudo do presente trabalho, serão enfatizados os aspectos morfofisiológicos da orelha interna, pois nele é que se localiza a cóclea, foco desta análise.

A primeira parte, a orelha externa, é composta pelo pavilhão auricular e pelo meato acústico externo (MAE) ou conduto auditivo, reponsáveis pela captação e condução do som. A segunda parte, a orelha média é representada pela cavidade timpânica e, por sua vez, começa na membrana timpânica e consiste em sua totalidade de um espaço aéreo - a cavidade timpânica - no osso temporal. Dentro dela, estão três ossículos articulados entre si, cujos nomes descrevem sua forma: martelo, bigorna e estribo; apresentam a função de transmissão e amplificação do som.

Por fim, tem-se a orelha interna, também chamada de labirinto, formada por escavações no osso temporal, revestida por membrana e preenchida por líquido. Limita-se com a orelha média pelas janelas oval e redonda. O labirinto apresenta uma parte anterior, a cóclea, relacionada com a audição, e uma parte posterior, relacionada com o equilíbrio e constituída pelo vestíbulo e pelos canais semicirculares ${ }^{24,25}$. 


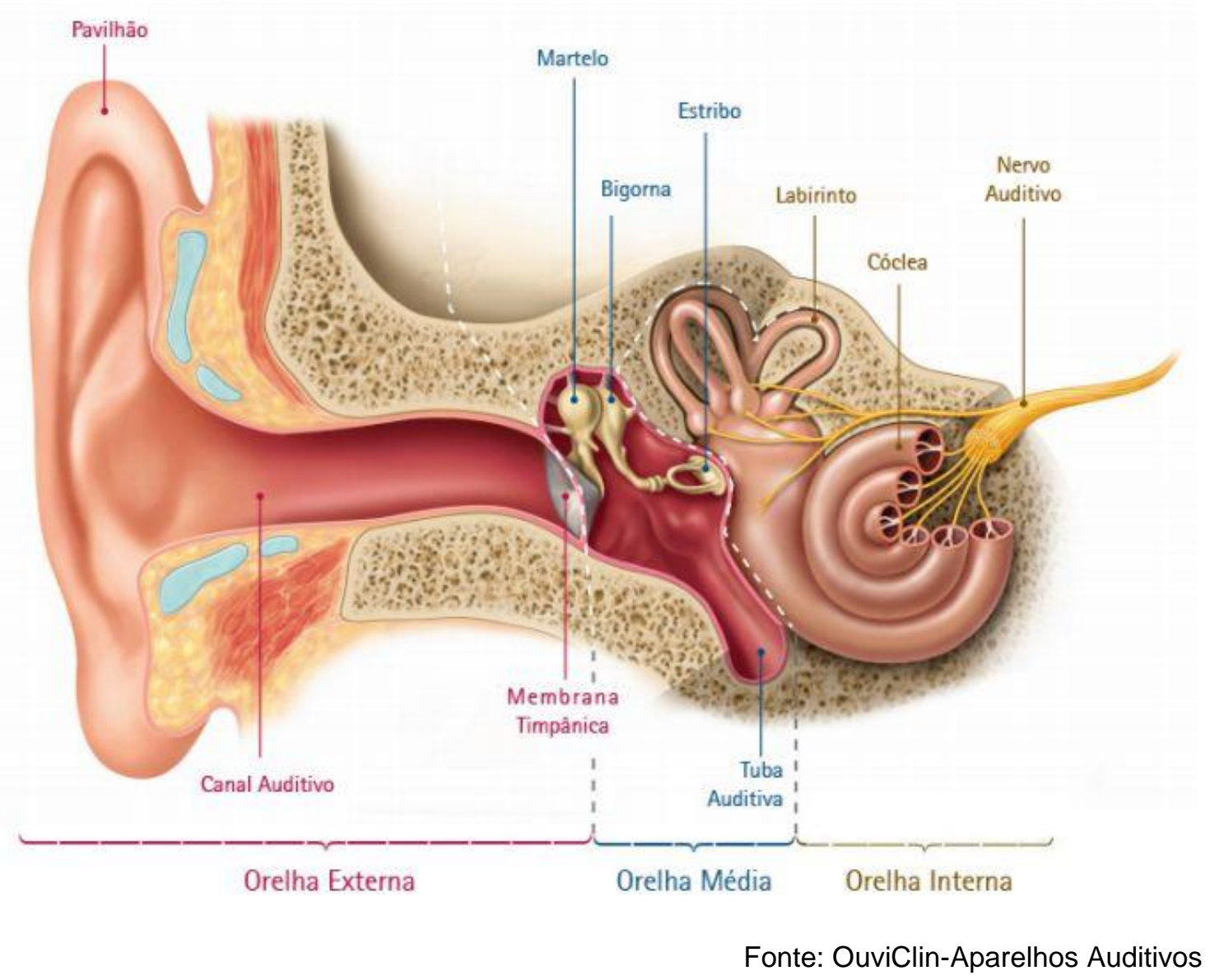

Figura 1- Ouvido Humano

É nesta parte do ouvido que se localiza a cóclea e nela se abriga o órgão de Corti, que contém as células auditivas sensoriais - as células ciliadas - as quais agem como microfones, convertendo o som e transmitindo-o ao cérebro via nervo auditivo (VIII par do nervo craniano). Há dois tipos de células ciliadas: a célula ciliada interna, que possui um corpo celular mais curto, arredondado e muitas fibras nervosas ligadas à sua base; e a célula ciliada externa, que possui um corpo tubular longo e menos fibras nervosas, que quando estimuladas, podem mudar a tensão dentro de suas paredes ${ }^{24}$. 


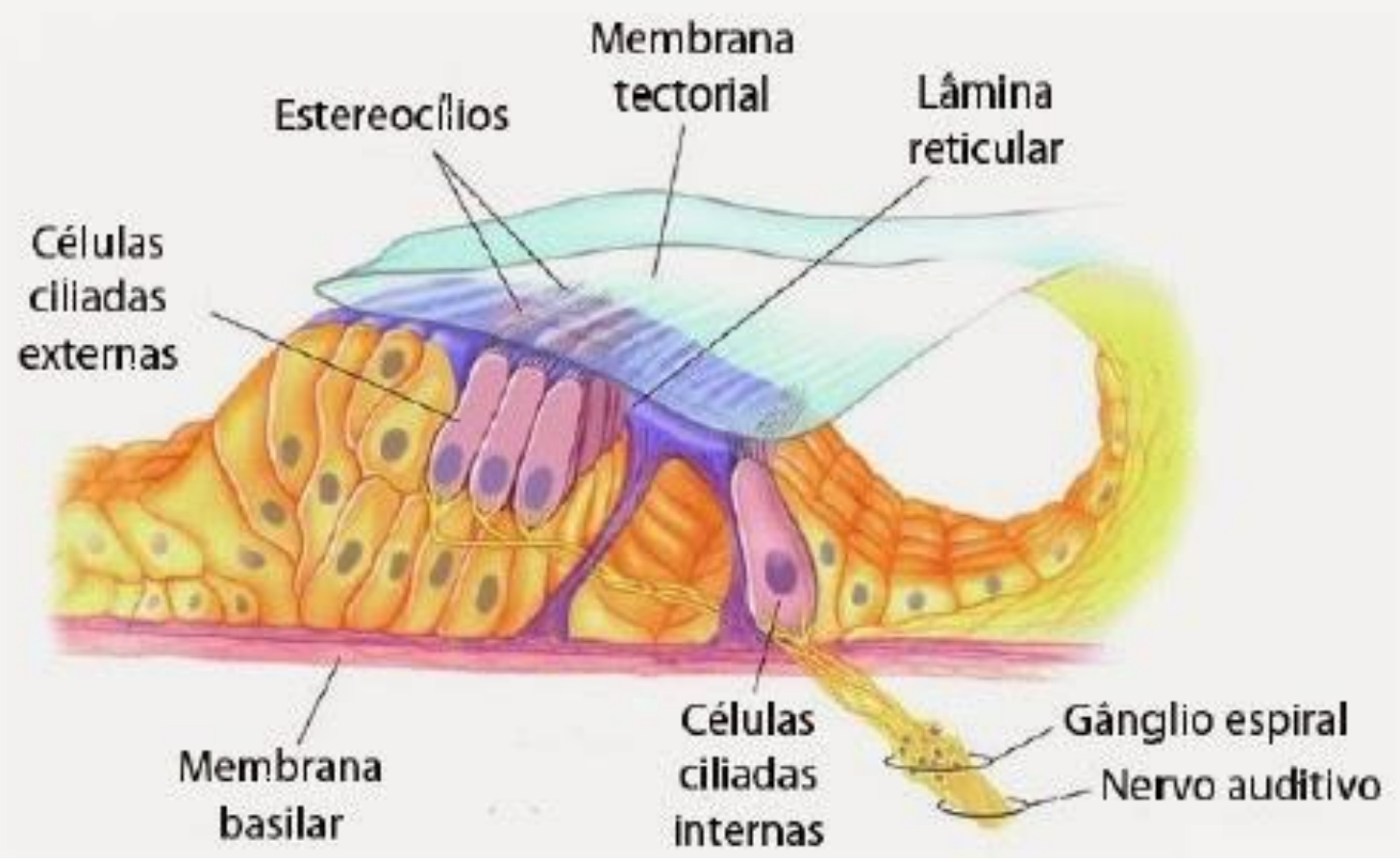

Fonte: $\mathrm{http}: / /$ fisioanimali.blogspot.com.br

Figura 2 - Orgão de Corti

A célula auditiva sensorial, ou célula ciliada, é o ponto focal do mecanismo da audição, pois ao ser estimulada pelo som, produz sinais elétricos que são transmitidos para o cérebro pelas fibras do nervo acústico. É um sentido essencial à vida, pois constitui a base da comunicação humana. Portanto, qualquer alteração no mecanismo das células ciliadas, consequentemente, ocasiona um comprometimento da audição ${ }^{26}$.

Ao estudar o movimento das células ciliadas, Kemp verificou que, depois de uma curta erupção de som, houve, após um breve atraso, uma produção de som da orelha interna. Esse som saído do ouvido era muito semelhante ao som que fora fornecido e, assim, Kemp o nomeou "eco" coclear ou, mais formalmente, emissões otoacústicas evocadas (EOAE). Porém, para ocorrência desses ecos, tinha que haver integridade das células ciliadas. Se elas têm um mau funcionamento, este eco reduz e é, então, perdido ${ }^{16,24}$.

Assim, as emissões otoacústicas, não apenas possuem um papel na teoria da audição, como também apresentam um potencial de prover um indicador bastante sensível de perdas auditivas, até mesmo aquelas em 
desenvolvimento, porque a ausência das emissões pode preceder uma perda auditiva.

\subsection{As EOA e a Influência do Ruído Social}

O ruído é o agente físico nocivo mais comum em nosso ambiente. A exposição ao ruído intenso lesa as células ciliares do órgão de Corti, causando perda irreversível da audição, doença conhecida como perda auditiva induzida pelo ruído (PAIR).

A PAIR instala-se de forma lenta e progressiva e caracteriza-se como uma perda auditiva do tipo neurossensorial, não muito profunda, quase sempre similar bilateralmente e absolutamente irreversível. Os padrões típicos da PAIR mostram uma perda auditiva na faixa de frequências altas, de 4 a $6 \mathrm{KHz}$ (Kilohertz), com perdas menores em frequências acima e abaixo dessa banda, formando o que comumente é chamado de entalhe ${ }^{27}$. Os afetados pela PAIR começam a ter dificuldades para perceber os sons agudos, tais como, telefone, apitos, campainhas e, logo, a deficiência se estende até a área média do campo audiométrico, comprometendo frequências relacionadas à fala e, consequentemente, afetando a comunicação. Alguns fatores podem influenciar sua ocorrência, entre eles, nível de pressão sonora, tempo, intensidade e frequência de exposição ao ruído e a suscetibilidade individual ${ }^{28}$.

A Portaria n. 19/1998, do Ministério do Trabalho ${ }^{29}$, denominou de "Perda Auditiva Induzida por Níveis de Pressão Sonora Elevados (PAINPSE)" os efeitos do ruído sobre a audição. É uma patologia caracterizada por alteração irreversível dos limiares auditivos, do tipo neurossensorial, com progressão gradual relacionada ao tempo de exposição ao risco.

O ruído pode ser social e ocupacional ${ }^{30}$, sendo o ruído ocupacional já bastante conhecido e estudado pela comunidade científica, está relacionado ao ambiente de trabalho, no qual o indivíduo fica exposto por um longo período. Já o ruído social está diretamente relacionado a ambientes de lazer, como boates, shows, bandas de rock, carros barulhentos, fones de ouvido, entre outros, geralmente de curta duração, mas - dependendo da frequência de uso ou 
assiduidade - são capazes de produzir efeitos deletérios sobre a saúde auditiva, comprometendo uma das mais importantes funções humanas, que é a comunicação ${ }^{30,31}$.

O ruído em alta intensidade pode desencadear rupturas mecânicas na membrana basilar e de suas células sensoriais, produzindo perdas auditivas imediatas de graus variados, as quais desencadeiam alterações temporárias ou permanentes do limiar auditivo. As perdas auditivas ocasionadas por exposição a níveis intensos de ruído surgem, primeiramente, de forma reversível, por meio de mudanças temporárias de limiar. Essas alterações do limiar de audibilidade vêm sendo intensamente analisadas, pois sua presença, em maior ou menor grau, sinaliza um prognóstico de suscetibilidade para perdas auditivas permanentes ${ }^{32,33}$.

Bouccara e colaboradores ${ }^{33}$ ressaltaram que os efeitos do ruído sobre a audição dependem, além das características físicas do ruído e do tempo de exposição, também de fatores individuais, uma vez que é grande a influência da susceptibilidade individual na instalação da PAIR. Uma exposição eventual a um ruído não tão intenso pode provocar uma alteração temporária de limiar, com recuperação à normalidade após algum tempo de repouso auditivo. Por outro lado, se o nível de pressão sonora for extremamente elevado (acima de 120 dBNA), pode-se formar um quadro de trauma acústico, caracterizado por instalação imediata de uma perda auditiva sensorioneural. Se as estruturas da orelha média forem atingidas, essa perda será mista ${ }^{34}$.

A perda auditiva temporária (TTS - Temporary Threshold Shift) é uma discreta perda auditiva, por um curto período de tempo, que ocorre após exposição a ruídos intensos. Isso acontece em virtude de as células ciliadas cocleares serem temporariamente danificadas depois de terem sofrido exposição a sons muito altos. Após um período de repouso (em silêncio), elas se regeneram. Porém, quando a exposição ao ruído passa a ser frequente, essas células tendem a não mais se regenerar, acarretando perdas permanentes. A perda auditiva permanente (PTS - Permanent Threshold Shift) é definida como uma perda irreversível, por exposição prolongada a ruído intenso, que se instala lentamente. Isso ocorre porque níveis extremos de stress auditivo atingem as células ciliadas externas, que são gravemente danificadas, sem regeneração posterior ${ }^{35,36}$. 
Pfeiffer e colaboradores ${ }^{35}$ verificaram mudanças temporárias do limiar de audição de seis músicos, do gênero masculino, componentes de uma banda de "rock", com idade entre 20 e 30 anos. Foram feitas anamnese ocupacional, determinação dos níveis mínimos de audição e medida do reflexo acústico, antes e após o show de rock. Quanto aos aspectos comportamentais relacionados ao ruído, os resultados mostraram que o zumbido foi a queixa mais presente entre os integrantes. Na audiometria tonal, as maiores diferenças pré e pós-exposição foram encontradas nas frequências altas, sendo a orelha direita a que apresentou maiores mudanças temporárias de limiar. Na medida do reflexo acústico após o show, a orelha direita obteve o maior percentual de ausência de reflexo (40\%). Os autores concluíram que músicos expostos a níveis elevados de pressão sonora apresentam alteração temporária do limiar e alteração do reflexo acústico.

Como acontece nas demais lesões auditivas, há surgimento de sintomas, auditivos ou não. O mais característico da PAIR é o zumbido, também chamado de acúfeno ou tinnitus, que pode ser definido como uma ilusão auditiva, isto é, uma sensação sonora produzida na ausência de fonte externa geradora de som. Isso significa que o zumbido é uma percepção auditiva fantasma, que pode ser notada apenas pelo acometido na maior parte dos casos, o que dificulta sua mensuração padronizada. A fisiopatologia do zumbido é ainda controversa. Trata-se de um sintoma que produz extremo desconforto, de difícil tratamento, podendo, de acordo com sua gravidade, excluir o indivíduo do convívio socia| $\left.\right|^{35,37,38}$.

Existem inúmeros estudos abordando a perda auditiva induzida por ruído no âmbito ocupacional e suas implicações aos trabalhadores a ele exposto. Entretanto, esse número é bastante reduzido quando se trata de perdas auditivas induzidas por níveis elevados de pressão sonora fora do ambiente de trabalho. Esses ruídos denominados de extraocupacionais podem também acarretar prejuízos à audição ${ }^{39}$.

Os efeitos do ruído sobre o funcionamento das CCE, após uma aula de aeróbica, foi objeto de estudo na pesquisa de Torre e Howell ${ }^{40}$. Participaram do estudo 50 sujeitos, sendo 48 mulheres e 2 homens, todos com audição normal. Os participantes realizaram avaliação de EOAPD, antes e após 50 minutos de aula. Os níveis de ruído foram mensurados por dosimetria e constatou-se média 
de 87 dBA. A comparação dos níveis das amplitudes (pré e pós exposição), obtidos mostraram redução na maioria das frequências testadas em ambas as orelhas.

A redução das amplitudes das EOAPD após exposição ao ruído com 20 homens e 20 mulheres, todos com audição até 25 dBNA e faixa etária entre 18 e 36 anos. Os sujeitos ficaram expostos durante 10 minutos ao ruído, dentro de uma cabina acústica. Após serem expostos, as amplitudes das EOAPD mostraram-se reduzidas em ambos os grupos. No grupo dos homens, todavia, a redução das amplitudes das EOAPD atingiu um número maior de frequências quando comparada ao grupo das mulheres. Não foi identificada diferença interaural significativa. Os autores concluíram que as EOAPD foram eficazes em detectar alterações cocleares após exposição ao ruído ${ }^{41}$.

Davis et al. ${ }^{42}$ monitoraram os efeitos do ruído nas CCE de 12 chinchilas. Constataram que o ruído causou uma redução nos níveis das amplitudes das EOAPD de aproximadamente $15 \mathrm{~dB}$. Houve perda de 15\% de CCE. Eles concluíram que a avaliação das EOAPD possui sensitividade em detectar alterações cocleares sutis. Recomendaram a utilização desse teste na rotina clínica audiológica e nos programas de conservação auditiva.

\subsection{Emissões Otoacústicas Evocadas}

As emissões otoacústicas (EOA) são sons registrados no conduto auditivo externo, gerados pela atividade fisiológica dentro da cóclea, mais especificamente pelas células ciliadas externas (CCE) do órgão de Corti. São respostas originadas na cóclea pelas células ciliadas que permitem avaliar a função coclear. Foram definidas por Kemp, em 1978, como "uma liberação de energia sonora produzida na cóclea, que se propaga pela orelha média até o meato acústico externo", e são observadas em indivíduos com integridade de função coclear $^{26}$. Para a obtenção das emissões otoacústicas, coloca-se uma sonda no conduto auditivo externo, a qual dispõe de um microfone capaz de capta-las para medi-las. As EOA classificam-se em espontâneas e evocadas - 
sendo a última subdividida em transiente (TE) e produto de distorção (PD) caracterizam-se por serem vulneráveis a agentes que danificam a cóclea de forma provisória ou permanente, como ruídos de forte intensidade e drogas ototóxicas $^{16,26}$.

As EOA espontâneas são registradas independentemente da apresentação de estímulo acústico, podendo ser observadas em 50\% dos indivíduos com audição normal e, justamente por isso, seu valor clínico ainda não está definido. Contudo, interferem no registro dos outros tipos de emissões em relação à amplitude. Por outro lado, as EOA evocadas surgem em consequência de um estímulo acústico ${ }^{26,28}$. Entre os tipos de emissões otoacústicas evocadas, as transientes e produtos de distorção são as que possuem maior aplicação clínica ${ }^{43}$.

De acordo com Bento et. $\mathrm{al}^{24}$ as emissões otoacústicas evocadas transientes (EOAT) são obtidas após apresentação de um estímulo de curta duração tipo clique na intensidade de 80 decibéis nível de pressão sonora (dBNPS), geralmente nas frequências de 1.000 a $4.000 \mathrm{Hertz}(\mathrm{Hz})$, que permite a estimulação da cóclea como um todo. Estão presentes em 98-99\% dos indivíduos com audição normal. A amplitude de resposta varia em função de idade, gênero e lado, e sofre interferência do nível de ruído, interno e/ou externo. As EOAT estão ausentes em indivíduos com perda auditiva leve (limiares tonais acima de $25 \mathrm{~dB}$ ) e são mais recomendadas para diagnóstico diferencial das alterações cocleares e, principalmente, para triagem auditiva em neonatos, por ser um teste objetivo, não invasivo e pela rapidez e facilidade da testagem ${ }^{26,44}$.

As emissões otoacústicas evocadas por produto de distorção são sons gerados pelas células ciliadas externas, evocadas por dois tons puros apresentados simultaneamente. Elas surgem como resultado de um estímulo sonoro. As EOAPD são obtidas após apresentação simultânea de dois tons puros denominados f1 e f2, com frequências sonoras muito próximas. Portanto, o produto de distorção é um terceiro tom produzido pela cóclea em decorrência de sua incapacidade de amplificar de forma linear dois estímulos diferentes ${ }^{26}$.

A EOAPD tem a vantagem de fornecer informações mais precisas para as frequências altas e a capacidade de avaliar um maior número de frequências, ou seja, avalia a cóclea desde a sua espira basal até apical. Elas estão presentes em indivíduos com audição normal e em perdas auditivas de até $35 \mathrm{~dB}$. Para o 
seu registro é necessária uma sonda com dois transdutores, que apresentarão os tons que serão misturados acusticamente, e o microfone para captação das emissões geradas. Podem ser avaliadas pelos níveis das amplitudes e da relação sinal/ruído, bem como pela latência que são mais eficazes na avaliação das bandas de frequências acima de $4 \mathrm{KHz}^{45}$.

Souza $^{46}$ relata que as EOAPD são mais sensíveis que as EOAT em detectar diferenças entre os grupos de indivíduos expostos a ruído e não expostos, haja vista que, entre os três critérios de avaliação (reprodutibilidade, amplitude e relação sinal/ruído), identificaram-se diferenças em dois: amplitude e relação sinal/ruído.

A pesquisa das EOA deve ser realizada em local silencioso, de preferência com nível de ruído de 40 dBNPS ou menos ${ }^{44}$. Antes do procedimento, é importante orientar o paciente e realizar a otoscopia para garantir condições adequadas do conduto auditivo externo e para verificar se há alteração de orelha média, que deverá ser considerada na análise do registro obtido. Por estarem presentes essencialmente em orelhas com função periférica normal, por meio delas é possível identificar os pacientes com perda auditiva coclear $^{44}$.

Com esse exame é possível detectar lesões nas células ciliadas externas da orelha interna, consideradas principais alvos de traumas sonoros ${ }^{47}$. Elas não quantificam a deficiência auditiva, porém detectam a sua ocorrência. Uma vez que estão presentes completamente, indicam que há integridade no funcionamento coclear. Trata-se de um exame não invasivo, sensível ao estado coclear, que não oferece danos, riscos ou desconforto, sendo rápido, indolor, sem contraindicação, de fácil aplicabilidade, com alta sensibilidade e especificidade para detectar alterações auditivas ${ }^{48-50}$.

Após três décadas da descoberta das EOA, observa-se um grande avanço na área da microfisiologia, relacionado às atividades bioquímicas e moleculares da cóclea.

O conhecimento do metabolismo coclear propiciou mudanças nos conceitos associados à forma como a cóclea processa os sons. Hoje, sabe-se que mecanismos bioeletrofisiológicos são realizados durante a transdução do estímulo acústico, no órgão de Corti, e que as CCE possuem um papel ativo neste processo. A eletromotilidade das CCE é responsável pelo aumento da 
vibração da membrana basilar na região de audiofrequência do estímulo que foi dado. Assim, elas participam da amplificação e da seletividade de frequências. Ainda hoje, considera-se que as EOA sejam a energia acústica advinda desse processo $^{51,52}$.

Devido à possibilidade de as EOA demonstrarem o status do funcionamento das CCE, este teste vem sendo adotado como procedimento de investigação auditiva em diversas situações clínicas: na triagem auditiva neonatal; no diagnóstico diferencial da perda auditiva neurossensorial; na exclusão das pseudohipoacusias; no monitoramento da audição, durante administração de ototóxicos; além do monitoramento da audição dos sujeitos expostos ao ruído ocupacional ${ }^{53}$.

Por esses motivos o teste das emissões otoacústicas evocadas vem se destacando dentre o conjunto de avaliações auditivas advindas da exposição ao ruído, não identificadas pela audiometria tonal ${ }^{28,54}$.

\subsection{Avaliação e Análise das EOA}

Foi ressaltada a importância dos níveis de intensidade utilizados na evocação das EOAPD, pois a intensidade do estímulo influencia os níveis das amplitudes ${ }^{55}$. Os níveis dos estímulos sonoros, conforme apontamentos da literatura, não devem ultrapassar 80 dBNPS. Acima desse valor, há risco de se ativarem os reflexos acústicos, aumentando a impedância da orelha média e podendo causar redução dos níveis de pressão sonora das amplitudes.

Um estudo ${ }^{56} \mathrm{em}$ sujeitos com e sem perda auditiva, verificou os diferentes parâmetros de intensidade no teste de EOAPD. O grupo sem perda auditiva foi formado por 80 sujeitos com limiares entre 0 a $20 \mathrm{dBNA}$, e o grupo com perda auditiva foi constituído por 89 trabalhadores expostos ao ruído industrial, com limiares auditivos comprometidos a partir de $3 \mathrm{KHz}$. Ambos os grupos realizaram duas avaliações de EOAPD, uma com a intensidade de $\mathrm{L} 1=\mathrm{L} 2=70 \mathrm{dBNPS}$, e outra com L1=65 e L2=55 dBNPS. Os achados do grupo sem perda auditiva foram indiferentes com relação às intensidades. Já, no grupo com perda auditiva, observou-se que as intensidades de L1=65 e L2=55 dBNPS apresentaram correlação estatística significante entre as respostas das EOAPD e os limiares 
auditivos dos participantes. Logo, concluíram que o parâmetro de L1=65 e L2=55 dBNPS parece ser o mais indicado na avaliação auditiva ocupacional para os sujeitos com e sem perda auditiva.

Sendo a cóclea um órgão fisiologicamente ativo, o fator idade pode interferir na ocorrência das EOA. Com a finalidade de identificar diferenças entre os registros dessas emissões nas diversas faixas etárias, um estudo ${ }^{57}$ realizou o teste de EOAPD em 180 orelhas de 96 sujeitos normo-ouvintes, com idade entre 14 e 82 anos. A amostra foi dividida em seis grupos etários: menores de 30 anos; 30-39 anos; 40-49 anos; 50-59 anos; 60-69 anos e maiores de 70 anos. Analisaram-se os valores das amplitudes na relação sinal/ruído (maior que 3 dBNPS) e os percentuais de ocorrência. Os resultados mostraram uma relação significativa entre aumento da idade e diminuição das amplitudes das EOAPD. Os percentuais de ocorrência mostraram-se significativamente mais reduzidos no grupo dos sujeitos mais velhos, principalmente no grupo com idade maior que 70 anos.

Azevedo ${ }^{26}$ fez referência à variabilidade dos níveis de amplitude das EOA de acordo com idade, gênero e orelha. Com relação ao gênero, as mulheres podem apresentar maiores amplitudes que os homens. As emissões otoacústicas espontâneas também podem estar associadas a uma maior prevalência de EOAT na orelha direita. Com relação à idade, as amplitudes decrescem com o envelhecimento e os valores de amplitude para EOAPD, variam entre 0 e $10 \mathrm{dBNPS}$ nos adultos, e entre 10 a 20 dBNPS no neonato. A redução das amplitudes relacionada à idade é geralmente atribuída aos efeitos do tamanho do meato acústico externo (MAE) e à integridade coclear.

Tendo como finalidade investigar mudanças na atividade das CCE com o avanço da idade, um estudo ${ }^{58}$ selecionou o teste das EOAPD e avaliou 331 sujeitos com limiares auditivos até $15 \mathrm{dBNA}$ nas frequências de 1, 2, 4 e $8 \mathrm{KHz}$. A amostra foi composta por homens e mulheres alocados em três grupos etários: 40-49 anos, 50-59 anos e 60 anos ou mais. Eles utilizaram o critério de análise da amplitude absoluta e avaliaram as frequências de 1 a $6 \mathrm{KHz}$. Os resultados mostraram uma associação entre aumento da idade e redução das amplitudes absolutas. Verificou-se também que os efeitos da idade sobre as EOAPD foram maiores nas mulheres do que nos homens. Neste último, o efeito negativo da idade nos níveis das amplitudes absolutas foi significante apenas na frequência 
de $1 \mathrm{KHz}$; já para as mulheres, houve redução significante das amplitudes absolutas nas frequências de 1 a $4 \mathrm{KHz}$.

Buscando verificar se há consistência nos registros das EOA, Barboni et al. ${ }^{59}$ estudaram a variação das amplitudes das EOAT, por meio da aplicação de teste-reteste em 35 sujeitos normo-ouvintes. Os sujeitos foram submetidos a três avaliações, com um intervalo de uma semana. Os pesquisadores não conseguiram quantificar a variação das amplitudes, pois os resultados revelaram um alto desvio padrão, demonstrando que as amplitudes podem apresentar grande variabilidade entre os sujeitos. Como a análise da variabilidade das amplitudes entre as testagens não foi estatisticamente significante, elas confirmaram a confiabilidade do teste de EOA.

\subsection{O Papel das EOA no Diagnóstico das Alterações Auditivas}

A avaliação e o monitoramento das perdas auditivas em geral são realizados por meio da audiometria tonal limiar, que determina a menor intensidade capaz de desencadear uma sensação auditiva em cada frequência testada. Contudo, pode não ser capaz de retratar a real situação do funcionamento da cóclea60.

No campo da audiologia ocupacional, a audiometria tonal limiar (ATL) representa o instrumento legal (PORTARIA n. 19/1998, do MINISTÉRIO DO TRABALHO) $)^{29}$ para o monitoramento da saúde auditiva dos profissionais expostos ao ruído. A saúde auditiva desses profissionais é monitorada pela realização de exames audiométricos periódicos, classificados como de referência ou sequencial, comparados e gerenciados por programas ocupacionais de saúde auditiva. Apesar do seu valor legal, autores como Barros et al. ${ }^{32}$ e o Comitê Nacional de Ruído e Conservação Auditiva ${ }^{27}$, reconhecem que a audiometria tonal é apenas um dos métodos que compõem a avaliação audiológica ocupacional, podendo, entretanto, apresentar algumas desvantagens como, por exemplo, a subjetividade. Já a aplicação de testes 
objetivos, como o teste de EOA - mais sensíveis à exposição ao ruído - permite a detecção precoce de alterações cocleares antes mesmo de elas serem observadas pela audiometria tonal e possibilita uma avaliação específica da funcionalidade das células ciliadas externas ${ }^{30,32}$.

$\mathrm{Na}$ literatura científica, muitos trabalhos relacionados às emissões otoacústicas evocadas em trabalhadores expostos ao ruído foram realizados $32,56,61-63$. No entanto, a maioria envolve a população do setor industrial, com jornada de trabalho geralmente de 8 horas diárias.

Diferentemente dos profissionais da indústria, os jovens não apresentam ciclo de exposição definido, por conta de uma exposição sonora não ocupacional e sim de lazer. Essa exposição acontece tanto aos ruídos de impacto comuns do dia-a-dia, quanto à música amplificada, pelo uso de fones de ouvido ou por frequentarem ambientes com música amplificada.

Portanto, as EOAPD complementam as EOAT, por verificarem o estado coclear em frequências mais altas, e são mais recomendadas para monitorização da função coclear em indivíduos que se expõem a ruídos intensos. Em casos de mudança na amplitude de resposta, há indícios de disfunção coclear com risco de lesão colear. A avaliação das emissões otoacústicas evocadas é um instrumento clínico efetivo para o monitoramento da cóclea, pois oferece múltiplas vantagens, o que permite a detecção de alterações cocleares sutis antes que sejam observadas na avaliação audiométrica tonal limiar. Além disso, é de grande valia no monitoramento da audição de grupos de indivíduos expostos a níveis elevados de pressão sonora ${ }^{32,54,64}$.

\subsection{Adolescentes e sua Relação com a Música Amplificada}

A música é vista como um som agradável e, por isso, é geralmente associada a fatos importantes da vida de cada indivíduo, proporcionando prazer a quem a ouve. Assim, ela é vista por muitos como sendo incapaz de causar algum dano ao ser humano. Contudo, quando usada de forma intensa e por um 
período longo de exposição, pode acarretar transtorno auditivo, alterando a qualidade de vida por uma indução à perda auditiva ${ }^{65,66}$.

A exposição contínua à música alta é considerada o fator mais importante para o aumento da prevalência de perda auditiva em jovens ${ }^{67}$. Uma pesquisa feita com 238 estudantes colegiais revelou um número significativo (44\%) de jovens que usam frequentemente equipamentos de som ${ }^{68}$. Estes, em sua maioria, relataram não acreditar que poderiam desenvolver uma perda auditiva ainda na juventude. Os jovens parecem não saber que ruídos de lazer relacionados à música (boates, shows, som de carro, fones de ouvido) podem acarretar prejuízos à audição.

Na prática clínica, já se observou um número elevado de jovens que estão ingressando no mercado de trabalho com achados audiológicos característicos de perda auditiva induzida por ruído, sem que antes tenham se exposto a ruídos ocupacionais. Um levantamento feito em Sorocaba - SP constatou que jovens, independentemente da classe social ou econômica, estão frequentemente expostos a níveis elevados de pressão sonora nas mais diferentes atividades. Do grupo de jovens avaliados, 45,3\% apresentaram algum tipo de alteração auditiva na faixa de frequência de 3 a $6 \mathrm{KHz}$. E quanto aos seus hábitos auditivos, $73,3 \%$, expõe-se principalmente à música coletiva excessivamente amplificada em discotecas, e 57,3\% usam fones de ouvido ${ }^{39}$.

Estudo realizado por Fissore et. $\mathrm{al}^{69}$, na cidade de Rosário - Santa Fé, com 65 adolescentes, por meio das emissões otoacústicas e audiometria tonal, revelou que $6 \%$ dos adolescentes apresentaram algum tipo de hipoacusia. Já os resultados com as EOAPD revelaram que $63 \%$ dos adolescentes apresentaram emissões otoacústicas produto de distorção com amplitudes diminuídas e $86 \%$ relataram apresentar sintomas posteriores à exposição de música elevada. Ainda nesse estudo foi observada a incidência de jovens que se expõem a música amplificada, relatando-se que, no grupo estudado, $76 \%$ admitiram usar fones de ouvidos e $91 \%$ têm hábitos de frequentar lugares com música amplificada. Os autores concluíram que uma elevada porcentagem de jovens conhece os efeitos nocivos do ruído e se coloca dentro de um grupo de risco. Também concluíram que alta porcentagem de adolescentes com audição normal, porém com emissões por produto de distorção diminuídas, poderia indicar, de forma precoce, uma disfunção coclear que ainda não é evidente na 
audiometria tonal e que estaria relacionada com os hábitos auditivos anteriormente mencionados.

Foram estudadas as alterações auditivas de adolescentes do ensino médio expostos a ruído recreativo e alguns fatores de risco associados. $\mathrm{O}$ estudo envolveu 214 adolescentes de uma escola da cidade do México, com faixa etária de 16 anos, sendo $73 \%$ do gênero masculino e $27 \%$ do gênero feminino. Foi aplicado um questionário com o objetivo de identificar os fatores de risco para alterações auditivas e feita avaliação audiológica com audiometria tonal e timpanometria. Na avaliação dos resultados, foram encontradas alterações auditivas em $21 \%$ dos adolescentes. Os principais fatores de risco associados a alterações auditivas foram: exposição a ruído recreacional; idas a discotecas/boates; shows de rock; uso de fones de ouvido e exposição a ruído nas "oficinas escolares". Concluiu-se que houve uma alta frequência (quase uma quinta parte) de alterações auditivas nos adolescentes do ensino médio associadas à presença de ruído recreativo excessivo ${ }^{70}$.

Pesquisa que identificou atitudes e hábitos auditivos de adolescentes diante do ruído (ambiental e lazer), envolveu 125 adolescentes, de ambos os gêneros, com média de idade de 16,7 anos, estudantes dos ensinos fundamental e médio de escolas de diversos municípios paranaenses ${ }^{71}$. Utilizou-se a versão brasileira do questionário Youth Attitude to Noise Scale (YANS), em português traduz-se "Atitudes dos jovens frente ao ruído"; para explorar a respeito dos hábitos auditivos. Os resultados referentes às atitudes dos adolescentes mostraram que 40,2\% concordam que barulhos e sons altos são aspectos naturais da nossa sociedade; $32 \%$ sentem-se preparados para tornar o ambiente escolar mais silencioso; 41,6\% consideram importante tornar o som ambiental mais confortável; e 38,4\% apresentam zumbido e consideramse sensíveis ao ruído. A maioria $(85,6 \%)$ dos entrevistados relatou não se preocupar antes de ir a shows e discotecas, mesmo com experiências precedentes de zumbido; $75,2 \%$ não fazem uso de protetor auditivo. Os autores concluíram que o comportamento de jovens dos ensinos fundamental e médio relacionado às atitudes e aos hábitos auditivos pode ser nocivo à saúde e que escutar música utilizando fone de ouvido, com equipamento de som em casa ou no carro foi o hábito mais frequente relatado pelos jovens. Eles observaram que grande 
parte deles apresenta zumbido, contudo isso não os preocupa nem os faz evitar exposições a elevadas intensidades sonoras.

Um estudo ${ }^{72}$, que envolveu 700 adolescentes com faixa etária entre 14 e 20 anos, verificou o grau de conhecimento de jovens adolescentes em relação às perdas auditivas induzidas por ruído. Os resultados demonstraram que, embora $88 \%$ da população estudada afirma ter conhecimento de que ruído de alta intensidade pode causar perdas auditivas, 90\% não sabe como proteger sua audição ou usam métodos ineficientes.

Foi realizado um estudo ${ }^{72}$ utilizando a audiometria associada às EOA para avaliar as alterações auditivas após exposição de 60 minutos ao walkman em alta intensidade, além da prevalência de sintomas como hipoacusia, plenitude auricular e zumbido. Foram analisadas 40 orelhas de voluntários cujas idades variaram de 22 a 30 anos, sendo 12 do gênero feminino e 8 do gênero masculino. Entre os indivíduos estudados, não havia história de surdez familiar, exposição a drogas ototóxicas ou de perda auditiva, estando o exame otorrinolaringológico dentro da normalidade. Todos os indivíduos estudados foram submetidos à audiometria tonal e a emissões otoacústicas por produtos de distorção. A seguir, foram expostos ao uso de walkman da marca AIWA TA 154, por 60 minutos, com música tipo rock pesado, na máxima intensidade tolerada por cada um dos voluntários. Essa intensidade foi estimada no ponto de maior energia sonora da primeira música e variou de 87 a 113dBNA. Imediatamente após a exposição ao walkman, repetiram-se a EOAPD e a audiometria tonal. Os voluntários foram interrogados quanto ao aparecimento de hipoacusia e/ou plenitude auricular, além de zumbido. Considerando a alteração dos produtos de distorção após uso de walkman, foi observada diferença significativa nas frequências de $3 \mathrm{KHz}$, $4 \mathrm{KHz}$ e $6 \mathrm{KHz}$, sendo que, na análise de produto de distorção subtraído do ruído de fundo (PD - RF) para cada frequência, houve diferença significativa nas frequências de $2 \mathrm{KHz}$ a $8 \mathrm{KHz}$. Quanto aos limiares nas diversas frequências da audiometria tonal, observou-se importante incidência de diferença dos limiares audiométricos nas frequências de $4 \mathrm{KHz}, 6 \mathrm{KHz}$ e $8 \mathrm{KHz}$. A hipoacusia e/ou a plenitude auricular após a exposição ao walkman ocorreram em $25 \%$, e o aparecimento de zumbido foi observado em $72,5 \%$ das orelhas. Esse estudo, por meio das emissões otoacústicas, da audiometria e do quadro clínico, 
confirma a presença de TTS pós-exposição ao walkman em alta intensidade, sendo mais atingidas as frequências de $4 \mathrm{KHz}$ e $6 \mathrm{KHz}$.

A perda auditiva induzida por ruído é um risco para os usuários de fones de ouvido. Autores ${ }^{73}$ fizeram essa afirmação após terem realizado um estudo com 80 sujeitos com média de idade de 11,2 anos, sendo 63\% usuários e 36,2\% não usuários de fones de ouvido. O resultado da audiometria tonal observou "trauma acústico" em $49 \%$ das orelhas dos usuários de fones de ouvido, e em $15,5 \%$ dos não usuários. O questionário aplicado foi capaz de identificar características entre usuários e não usuários de fones de ouvido, assim como os sujeitos com e sem alteração auditiva. Nessa pesquisa, registrou-se "dano" auditivo em mais do dobro das orelhas dos usuários de fones de ouvido em comparação com os não usuários.

Segundo estudo da ASHA, realizado em 2006, os testes feitos em walkmans e tocadores de MP3 mostraram que todos são capazes de reproduzir música acima dos $100 \mathrm{~dB}$ (decibéis), e pessoas que frequentam boates e shows também são expostos a sons acima de $100 \mathrm{~dB}^{36,37}$.

A evolução da eletrônica e o gradativo aumento da potência dos amplificadores acoplados aos instrumentos musicais modernos levam ao aumento da intensidade da música e têm provocado efeitos nocivos à audição, especialmente dos músicos. Na década de 60, eram empregados amplificadores de 100 watts nos concertos de rock, porém sua potência aumentou para 20.000 e 30.000 watts, e os alto-falantes podem atingir valores situados entre 100.000 e 500.000 watts $^{31,66,74}$.

Foram relatados ${ }^{74}$ os níveis de pressão sonora mínimos e máximos detectados em bandas de trios elétricos, os quais variam de 104 a $114 \mathrm{~dB}$ e, nas bandas de rock, são de 102 a $116 \mathrm{~dB}$. Com uma intensidade na magnitude de $100 \mathrm{~dB}$, o indivíduo poderia ficar exposto, no máximo, uma hora por dia, já a $115 \mathrm{~dB}$ são permitidos apenas sete minutos diários. Os mecanismos de proteção da orelha são eficazes na exposição até 85 a $90 \mathrm{dBNA}$, causando prejuízo às estruturas auditivas os níveis de intensidade acima desses valores. Portanto, o ouvido humano é capaz de suportar sons entre 0 e 90 dBNPS, porém os que excedem esse limite, tornam-se desconfortáveis e dolorosos (BRASIL. MINISTÉRIO do TRABALHO e EMPREGO. Portaria 3.214 de jul. 1978) ${ }^{75,76}$. Os 
sons que se aproximam de $130 \mathrm{~dB}$ NPS podem causar lesões destrutivas ao aparelho auditivo ${ }^{76}$.

A legislação brasileira afirma que os níveis sonoros que excedem a $85 \mathrm{~dB}$, sejam eles gerados por fones de ouvido, ambiente de trabalho ruidoso, brinquedos sonoros, atividades domésticas e recreacionais, podem acarretar danos à saúde e, principalmente, à audição do indivíduo ${ }^{77,78}$.

No Brasil, não consta nas normas da ABNT (Associação Brasileira de Normas Técnicas) nenhuma diretriz de controle do ruído em atividades de lazer. Existe, para o ambiente industrial, a Norma Regulamentadora (NR 15), que estipula o máximo de 85 dB para uma exposição de oito horas diárias ao ruído contínuo ou intermitente. Analisando a tabela que consta na NR 15, basta aumentar de 3 a $5 \mathrm{~dB}$, a partir do limite de $85 \mathrm{~dB}$, para que o tempo máximo de exposição ocupacional recomendado caia pela metade, ou seja, para quatro horas. Conforme a norma, se o ruído for de $115 \mathrm{~dB}$, o tempo de exposição permitido é de sete minutos e, acima desse nível, desaconselhável sem o uso de protetores auditivos (BRASIL. MINISTÉRIO DO TRABALHO E EMPREGO. PORTARIA 3. 214, 1978) $)^{75}$.

A Suécia é um dos poucos países que tem recomendações específicas e limites de segurança ocupacional no que diz respeito ao ruído no trabalho e em atividades musicais, tanto para músicos quanto para ouvintes. Para os ouvintes, a recomendação da Diretoria Nacional de Saúde e Bem-Estar Social da Suécia é estabelecida em $100 \mathrm{~dB}$, sendo que o valor máximo durante uma apresentação musical é de 115 dB. Já para os músicos, a Administração Sueca de Saúde e Segurança Ocupacional tem regulamentado, no cálculo de risco de perda auditiva, $85 \mathrm{~dB} / 8 \mathrm{~h}$, com $115 \mathrm{~dB}$ e $140 \mathrm{~dB}$ de pico como nível máximo ${ }^{31,36,67}$. Em alguns lugares onde os jovens costumam se encontrar, como bares, boates, shows e outros, geralmente a intensidade do som é superior a $100 \mathrm{~dB}$ e, nos equipamentos portáteis, como os fones de ouvido, pode até ultrapassar esse nível ${ }^{36}$.

Por isso, vem aumentando cada vez mais a preocupação com a perda auditiva induzida pelo ruído a que os jovens ficam suscetíveis durante as atividades de lazer (prática de esportes em ginásios e/ou academias, frequência a boates e o uso de equipamentos portáteis, como os fones de ouvido). Isso pode ser notado por alguns estudos científicos já realizados, principalmente os 
internacionais ${ }^{36,79-84}$. Já na literatura nacional, há carência de estudos com jovens expostos a níveis sonoros elevados. Entretanto, a integridade auditiva desses jovens pode estar relacionada com seu estilo de vida e suas preferências nas atividades de lazer ${ }^{85}$. 


\section{MÉTODOS}

\subsection{Aspectos Éticos}

Trata-se de um estudo epidemiológico analítico retrospectivo, observacional, do tipo caso-controle. O presente estudo obedeceu às normas da Resolução 196/96 (BRASIL, 1996), e foi submetido à análise do Comitê de Ética em Pesquisa da Faculdade de Medicina da Universidade de Brasília, com aprovação em 23 de maio de 2014, sob o protocolo de nº 059.058 (Anexo I)

A participação da amostra neste estudo foi voluntária e gratuita. $O$ Termo de Consentimento Livre e Esclarecido - TCLE (Apêndice A) foi entregue em sala de aula. Os maiores de 18 anos assinaram na própria escola e os menores de 18 anos levaram-no para casa, a fim de que os pais e/ou responsáveis legais o assinassem, consentindo e autorizando a participação na pesquisa e a divulgação dos resultados.

\subsection{Local de aplicação do estudo}

O estudo foi realizado em 3 escolas de Ensino Médio do Distrito Federal. Vale salientar que o projeto de pesquisa foi apresentado à direção de várias instituições de ensino da cidade de Brasília, porém, apenas 3 delas se colocaram à disposição para contribuir com a pesquisa, autorizando sua realização. Posteriormente, foi formalizado o compromisso e data de início da coleta. Todos os procedimentos foram realizados nas dependências da própria instituição sem que houvesse necessidade de deslocamento dos alunos.

A coleta foi realizada em uma sala reservada da escola, com baixo nível de ruído, escolhida pela instituição e em concordância da pesquisadora. A mensuração prévia do nível de ruído foi realizada por profissional habilitado, compondo laudo técnico (Anexo II) foi de 40.6dB. 


\subsection{Sujeitos do Estudo}

Utilizou-se para este estudo uma amostra de conveniência composta por adolescentes, estudantes do ensino médio, de ambos os gêneros, com faixa etária entre 13 e 18 anos, que estivessem de acordo com os critérios de seleção estabelecidos para o estudo descritos a seguir. A fim de determinar a inclusão ou exclusão dos sujeitos na presente pesquisa, foi realizada uma anamnese (Apêndice B) seguindo um protocolo de seleção composto de perguntas referentes à perda de audição, doenças da orelha e estado geral de saúde.

\subsubsection{Critérios de Inclusão}

Para este estudo, os seguintes itens foram considerados como critérios de inclusão:

- Submeter-se aos exames de audiometria, imitanciometria e EOA evocadas;

- Responder ao questionário sobre hábitos auditivos;

- Ser aluno regular da instituição de ensino

- Ter entre 13 e 18 anos de idade;

\subsubsection{Critérios de Exclusão}

- Ter história prévia de perda auditiva;

- Estar em uso de medicamentos ototóxicos;

- Fazer uso de aparelho de amplificação sonora individual (AASI);

- Apresentar problemas da orelha externa ou média;

- Apresentar queixas e/ou sintomas de doença otológica;

- Apresentar limiares acima de $25 \mathrm{~dB}$ no exame da audiometria;

- Apresentar curvas timpanométricas tipo "B" ou "C" e ausência de reflexos acústicos em todas as frequências. 


\subsection{Materiais e Procedimentos}

Foram utilizados para realização da pesquisa os seguintes materiais:

- Otoscópio e espéculos, marca Mikatos para inspeção do conduto auditivo;

- Audiômetro marca Vibrasom, modelo AVS-500 com itens de série e cabine acústica;

- Cabine acústica modelo VSA-40, marca Vibrasom;

- Impedanciômetro, marca AZ-7 com itens de série como sonda e olivas;

- Aparelho de Emissões Otoacústicas portátil e itens de série, como sonda e olivas de diversos tamanhos, marca MAICO, modelo ERO-SCAN, ano de fabricação 2006;

- Notebook marca DELL, modelo Inspiron 13, configuração Windows 10, CORE-i7 para transferência e análise dos dados examinados.

\subsubsection{Procedimentos}

$\mathrm{Na}$ primeira etapa da pesquisa, os sujeitos foram pré-selecionados seguindo os critérios de inclusão e exclusão por meio da anamnese. Neste momento, foi realizada a inspeção do conduto auditivo externo para visualização de possível presença de cerúmen e outros agentes que poderiam interferir na realização do exame. Os indivíduos que apresentaram presença de cerúmen foram encaminhados para a clínica de otorrinolaringologia para avaliação.

Em seguida, na segunda etapa, os participantes foram submetidos aos exames de audiometria tonal limiar, imitanciometria e emissões otoacústicas evocadas por estímulo produto de distorção, detalhados no item 4.5. Foram dadas informações acerca de cada exame e instruções de posicionamento, respostas, entre outras, tais como evitar movimentos, ser indolor e de rápida execução.

$\mathrm{Na}$ etapa seguinte, precedendo a realização do estudo, os participantes responderam a um breve questionário (Apêndice $\mathrm{C}$ ) com questões objetivas 
referentes ao uso de fones de ouvido e a frequentar lugares com música amplificada; com a finalidade de caracterizar o perfil dos participantes, em relação à exposição sonora. Ao final da pesquisa, os alunos receberam um texto informativo a respeito da audição e dos riscos de exposição a sons de alta intensidade para conhecimento e prevenção de hábitos nocivos à saúde (Anexo III).

\subsection{Avaliação da audição e critérios para a análise dos resultados}

Primeiramente, ressalta-se que os exames foram realizados em ambiente favorável, em horário matutino, apropriado devido ao repouso auditivo. A primeira etapa foi iniciada com a anamnese e otoscopia conforme descrito anteriormente.

Na segunda etapa, em que houve a realização dos exames iniciando pela determinação dos limiares tonais, foi utilizado tom puro em cabine acústica, com o audiômetro e fones supra-aurais nas frequências de 250, 500, 1.000, 2.000, $3.000,4.000,6.000$ e $8.000 \mathrm{~Hz}$. O critério de normalidade adotado foi de limiares auditivos iguais ou menores que $25 \mathrm{~dB}$ bilateralmente em todas as frequências (Lloyd e Kaplan, 1978).

As medidas de imitância acústica, abrangendo a timpanometria e a pesquisa do reflexo acústico do músculo estapédio, foram obtidas por meio da imitanciometria no modo manual. Foi considerado como padrão de normalidade curva timpanométrica tipo "A" e reflexos acústicos Ipsilaterais e Contralaterais presentes na intensidade de 70 a $100 \mathrm{~dB}$ NS, na maioria das frequências avaliadas: 500, $1.000,2.000$ e $4.000 \mathrm{~Hz}$. Ressaltando que, também foram consideradas as curvas tipo "Ar" e "Ad" como normalidade desde que os reflexos acústicos estivessem presentes em todas as frequências (Gelfand, 1984 e Jerger e Jerger, 1989).

As emissões otoacústicas evocadas por produto de distorção (EOAPD) foram testadas em ambas as orelhas, tendo sido aleatória a escolha da primeira orelha a ser avaliada, por meio do equipamento específico, nas frequências de $2.000,4.000,6.000,8.000,10.000$ e $12.000 \mathrm{~Hz}$, com intensidades de $\mathrm{L} 1=65 \mathrm{e}$ 
$\mathrm{L} 2=55$, utilizando-se como estímulo acústico dois tons puros ( $F 1$ e F2), apresentados simultaneamente - com frequências sonoras pareadas observando a relação tal que $F 1 / F 2=1,22$. Nesses parâmetros, foi adotado 0 critério PASSA/FALHA em que foram avaliadas a amplitude do sinal e a relação sinal ruído $(S / R)$.

Como normalidade foram consideradas a amplitude do sinal igual ou inferior à $-5 \mathrm{~dB}$ e a relação $\mathrm{S} / \mathrm{R}$ igual ou superior a $6 \mathrm{~dB}$ para todas as bandas de frequência avaliadas. Lembrando que esses valores caracterizam uma resposta presente e que foram adotados os termos "PASSA" e "FALHA" para os devidos resultados "NORMAIS" e "ALTERADOS" respectivamente. Os exames considerados "Passa" foram os que apresentaram amplitude e relação sinal/ruído dentro da faixa de valores acima mencionados, em todas as frequências e nas duas orelhas. E os exames considerados "Falha", foram os que apresentaram valores de amplitude e relação $S / R$ inferiores ao mencionado, em pelo menos uma frequência e em qualquer uma das orelhas. Vale ressaltar que foi utilizado o programa padrão do equipamento baseado no manual do fabricante para seus registros. O analisador de emissões otoacústicas usado neste estudo monitorou automaticamente o nível de ruído, a linearidade do estímulo durante o teste e o posicionamento adequado da sonda. A figura 3 exemplifica o gráfico computadorizado de um exame EOAPD do equipamento utilizado na pesquisa.

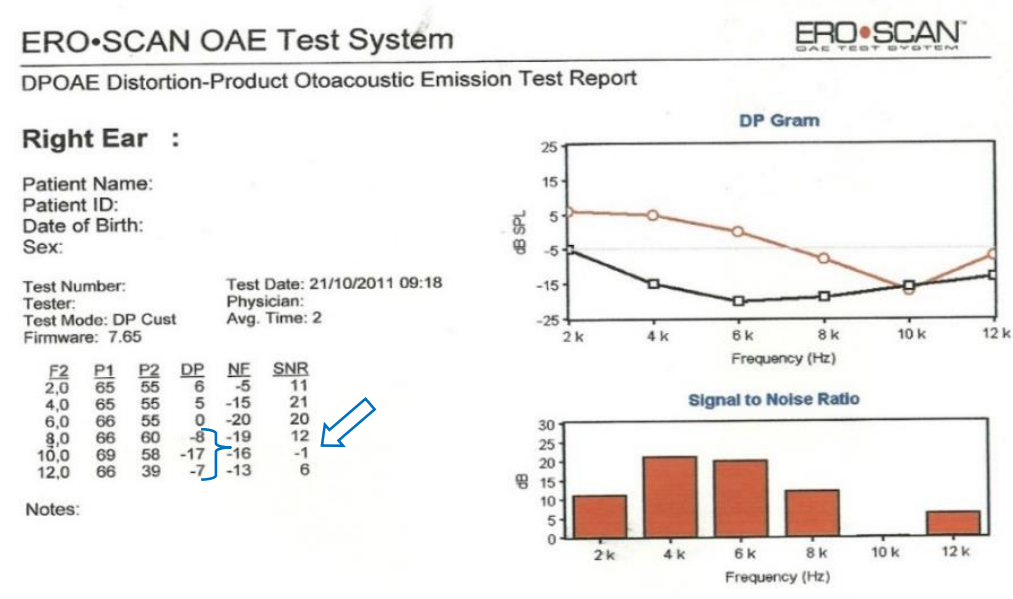

Figura 3 - Modelo de descrição de resultados do exame de EOAPD "Falha" computadorizado. 
$\mathrm{Na}$ terceira e última etapa, a fim de obter informações referentes aos hábitos auditivos, na qual a resposta de letra "A" foi considerada como hábitos de risco para a saúde auditiva e a de letra "B" foi considerada como comportamento de baixo risco para saúde auditiva.

\subsection{Definição da Amostra}

A etapa de recrutamento de participantes teve início em agosto de 2013 com a apresentação do projeto nas escolas, e a coleta de dados se iniciou em março de 2014, encerrando-se em dezembro do mesmo ano.

Participaram do estudo 112 estudantes sendo excluídos 23 indivíduos. Destes, 12 apresentaram problemas de orelha média como presença de cerúmen, 4 por aumento nos limiares tonais; 3 por apresentarem resultados alterados de imitanciometria, 4 por inconsistência nas respostas ao questionário. Portanto, o estudo prosseguiu com 89 indivíduos restantes em que 59 apresentaram emissões otoacústicas alteradas, ou seja, "FALHA" em uma ou em ambas as orelhas, e foram, portanto, alocados no grupo caso. 30 participantes apresentaram emissões otoacústicas normais, ou seja, "PASSA" em ambas as orelhas, sendo alocados no grupo controle.

Para uma melhor equivalência entre os grupos e para que a análise fosse realizada de forma pareada (relação 1 por 1), conforme planejamento do estudo melhor detalhado no item 4.7, foram excluídos 29 indivíduos aleatoriamente por excesso de participantes para o grupo caso. Desta forma, a amostra para o estudo final foi composta por 60 jovens, sendo 30 casos e 30 controles.

Cada grupo foi subdividido em grupos de expostos e não expostos. Essa subdivisão foi realizada a partir do levantamento da frequência de uso do fone de ouvido e por frequentar lugares com música amplificada, por meio do questionário elaborado para o presente estudo. O critério para a seleção dos sujeitos expostos à música de alta intensidade e os não expostos foi: sujeitos que assinalaram $100 \%$ das questões de letra "A" foram alocados no subgrupo 
"exposto" e os que assinalaram 100\% das questões de letra "B", foram considerados como "não expostos".

É importante enfatizar que, para cada grupo (caso e controle), foram alocados sujeitos expostos e não expostos de acordo com o critério de delineamento do estudo, conforme demonstrado na Figura 4.

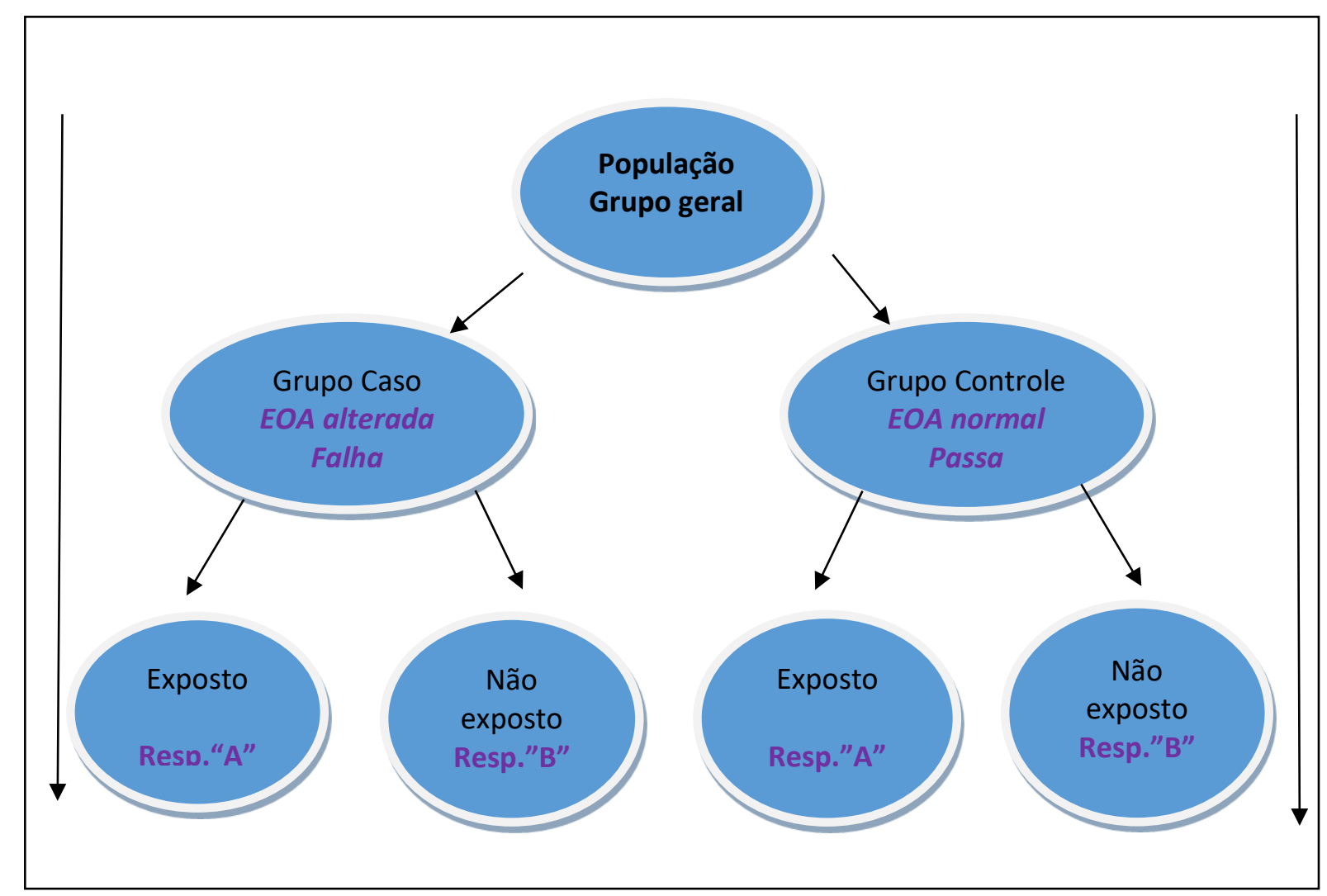

Figura 4 - Organograma de formação dos grupos da pesquisa e delineamento do estudo.

\subsection{Métodos Estatísticos}

O tamanho da amostra para o estudo caso-controle foi calculado no programa Epi-Info Versão 3.3.2; para um grau de confiança de 95\%, erro alfa de $5 \%$, erro beta de $20 \%$ e odds ratio (OR) estimado em 5 , a uma relação de um controle para cada caso, resultou em 13 indivíduos para o grupo caso e 13 para o grupo controle. 
Os dados coletados foram digitalizados e transferidos para uma planilha do Excel, para posterior análise estatística. Os resultados foram reportados apresentando-se uma estatística descritiva: média, valor mínimo e máximo, desvio padrão e valor absoluto (n) conforme as variáveis estudadas: amplitude do sinal, relação sinal/ruído, gênero, idade, lado da orelha, tipo de curva e reflexos.

Quanto à análise estatística, as variáveis dependentes estudadas foram amplitude do sinal, relação sinal/ruído, verificando-se a existência ou não de associação com a variável independente "exposição à música amplificada", utilizando-se o teste do Qui-quadrado e o IC de 95\% para avaliar a significância estatística da calculada Razão de Chances (Odds Ratio). O nível de significância estatística foi estabelecido em $5 \%(p<0,05)$. Foi utilizado o Programa Epi-Info Versão 3.5.1. 


\section{RESULTADOS}

Dos 89 participantes restantes pré-selecionados, 59 apresentaram resultados de EOAPD alterados (Falha) e 30 normais (Passa). Para que houvesse uma equivalência entre os grupos, excluiu-se aleatoriamente 29 participantes com exames alterados e, portanto, o estudo caso-controle foi realizado com 60 sujeitos sendo 30 apresentando exames alterados ou "falha", alocados no grupo caso e 30 com exames normais ou "passa", alocados no grupo controle. Todos os sujeitos selecionados para o estudo apresentaram limiares auditivos dentro do padrão de normalidade.

\subsection{Análise descritiva}

\subsubsection{Gênero}

Participaram 60 indivíduos sendo 34 (56,7\%) do gênero feminino e 26 $(43,3 \%)$ do gênero masculino, sem diferença estatisticamente significante (Figura 5).

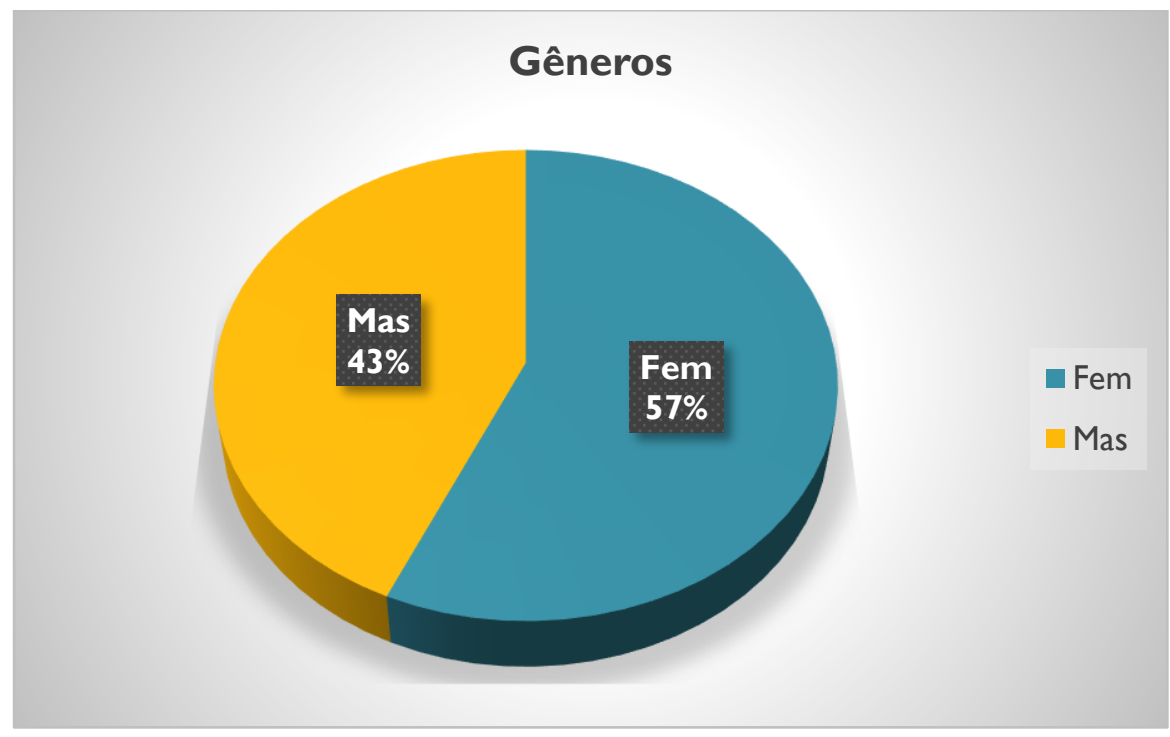

Figura 5 - Distribuição dos participantes segundo gênero 


\subsubsection{Idade}

A idade média dos participantes foi de 15,1 anos $(+-1,2)$ e, como é visto na figura 6, a maioria dos participantes tinha entre 13 (mínimo) e 18 anos (máximo).

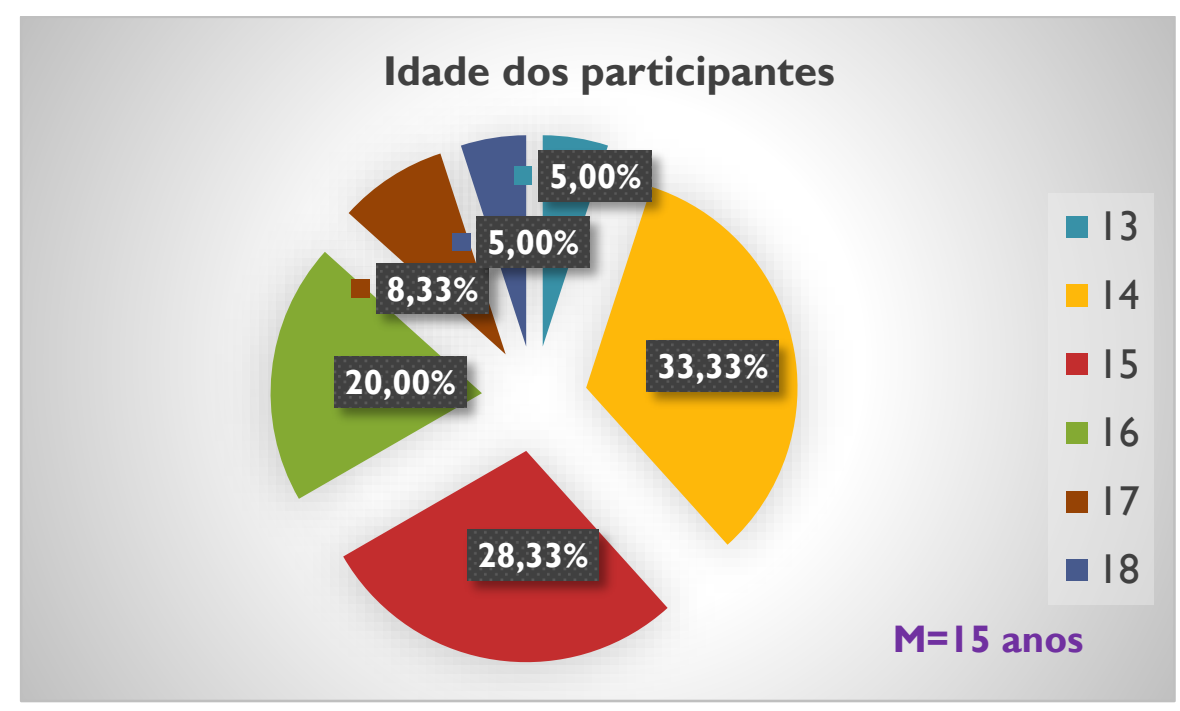

Figura 6 - Distribuição de idade apresentada pelos participantes.

\subsubsection{Emissões Otoacústicas}

Em ambas as orelhas, houve um maior número de participantes que passaram no exame. Na orelha esquerda houve um número maior de falhas. Nos resultados da orelha esquerda, 45\% (27) dos participantes falharam e 65\% (33) passaram. Já na orelha direita $30 \%$ (18) dos participantes falharam no exame e $70 \%$ (42) passaram (Figura 7). 


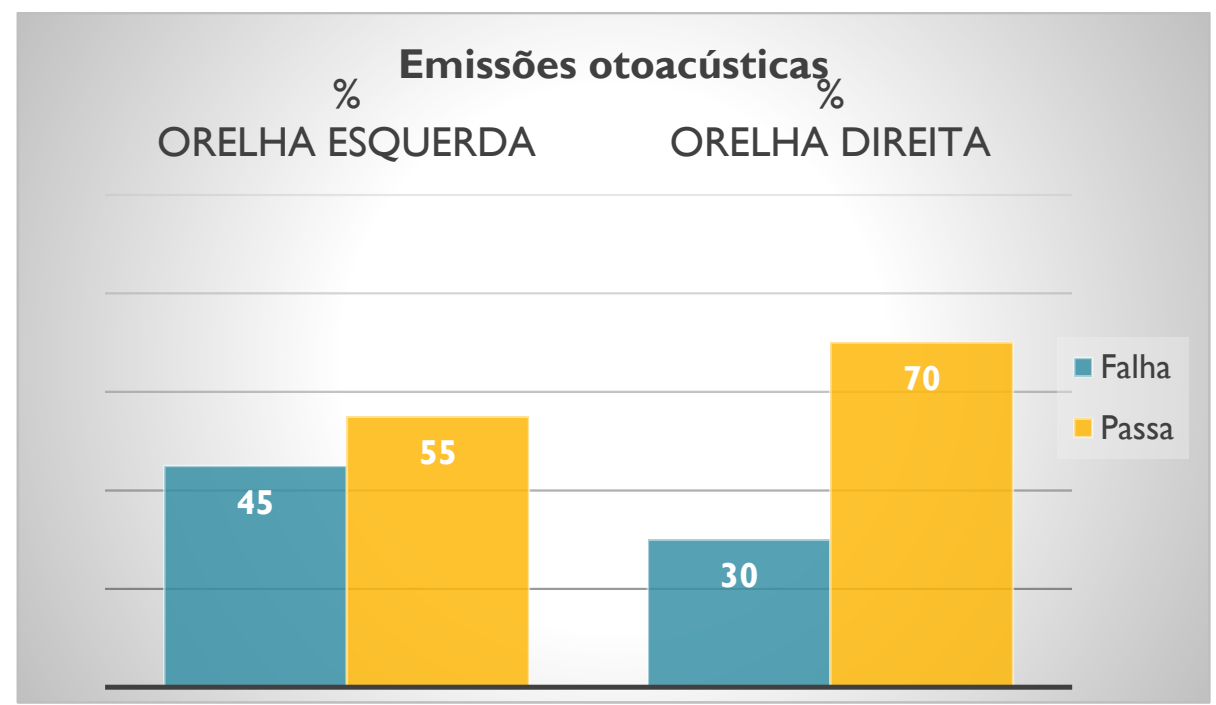

Figura 7 - Resultado do Exame de EOA dos Participantes por Orelha

A partir destes resultados, ocorreu a divisão dos grupos caso e controle conforme a distribuição dos resultados Passa e Falha.

\subsection{Análise das Correlações - Caso-Controle}

A seguir, estão apresentadas as análises de correlação das variáveis referentes aos grupos caso e controle.

\subsubsection{Gênero segundo grupos}

Quanto à distribuição de gênero segundo grupos de estudo, no grupo caso $60 \%$ dos participantes eram do gênero feminino e $40 \%$ do gênero masculino. Já entre os alocados no grupo controle 53,3\% dos participantes eram do gênero feminino e $46,7 \%$ do gênero masculino (Figura 8). Entretanto, não houve diferenças estatísticas significantes entre os gêneros e os grupos caso e controle $(p=0,79)$. 


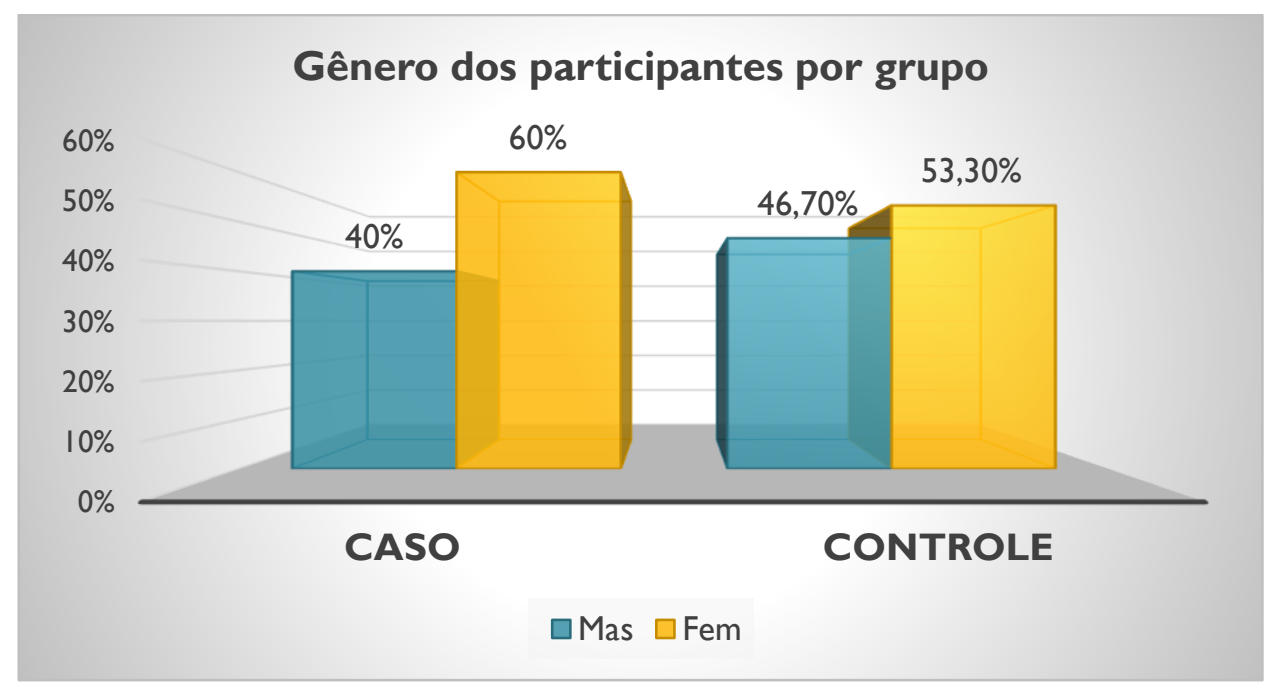

Figura 8- Gênero dos Participantes do Estudo segundo Grupo

\subsubsection{Idade segundo grupos}

No que se refere à distribuição da idade segundo grupo de estudo, observou-se idade média de 15 anos, sendo que cerca de $80 \%$ dos participantes em ambos os grupos tinham esta faixa etária. Foi possível verificar que, no grupo caso, os participantes apresentaram idade média superior ( $M=15,4$ anos/d.p. 1,3/min-14 anos/max-18 anos), quando comparados aos participantes do grupo controle ( $M=14,8$ anos/d.p.1,1/min-13 anos/max-17 anos) (Figura 9). Tais diferenças foram estatisticamente significantes $(p=0.017)$ e podem ser visualizadas na figura 9. 


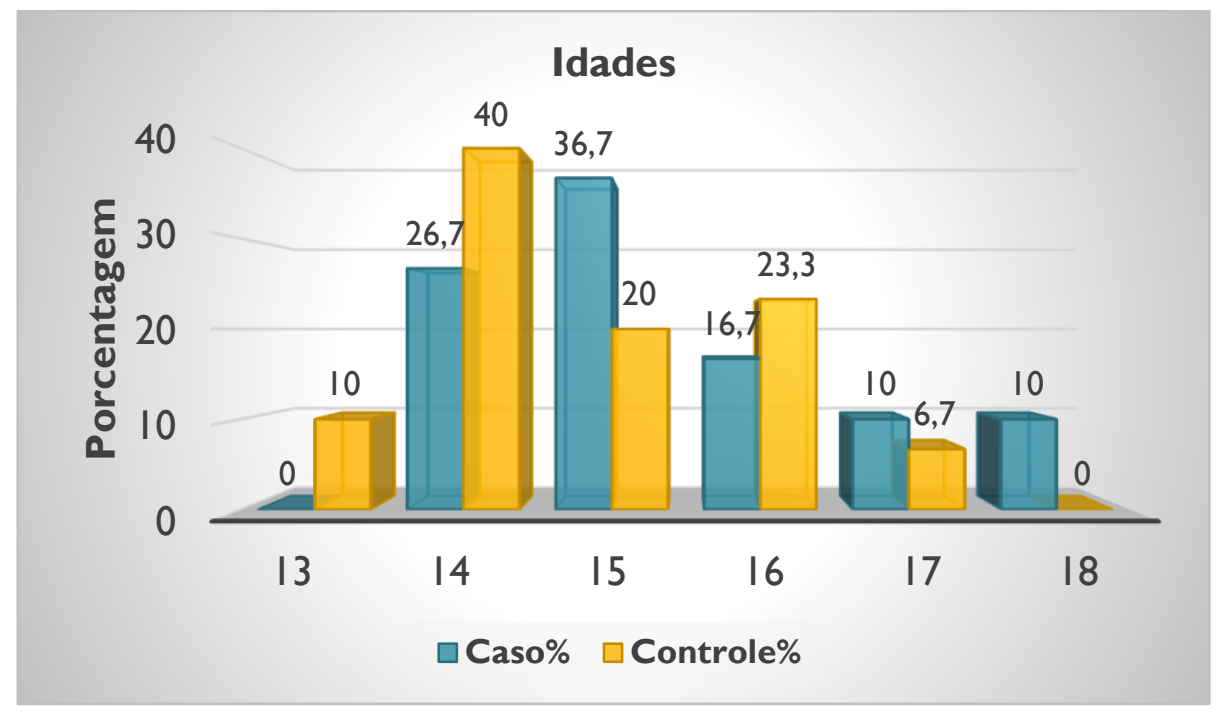

Figura 9 - Distribuição percentual das idades dos participantes segundo grupo

\section{3 - Exposição ao Risco - Exposto e Não-exposto}

\subsubsection{Gênero segundo grupos de exposição}

Segundo a exposição ao risco, nota-se que as frequências da variável gênero, não se distribuíram de forma igualitária, porém não caracterizou diferença estatisticamente significante $(p=0,37)$ entre os grupos. A maioria dos participantes do estudo que foram expostos ao risco era do gênero feminino, sendo que ocorreu o inverso entre os participantes não expostos que, em sua maioria, foram do gênero masculino (Figura 10). 


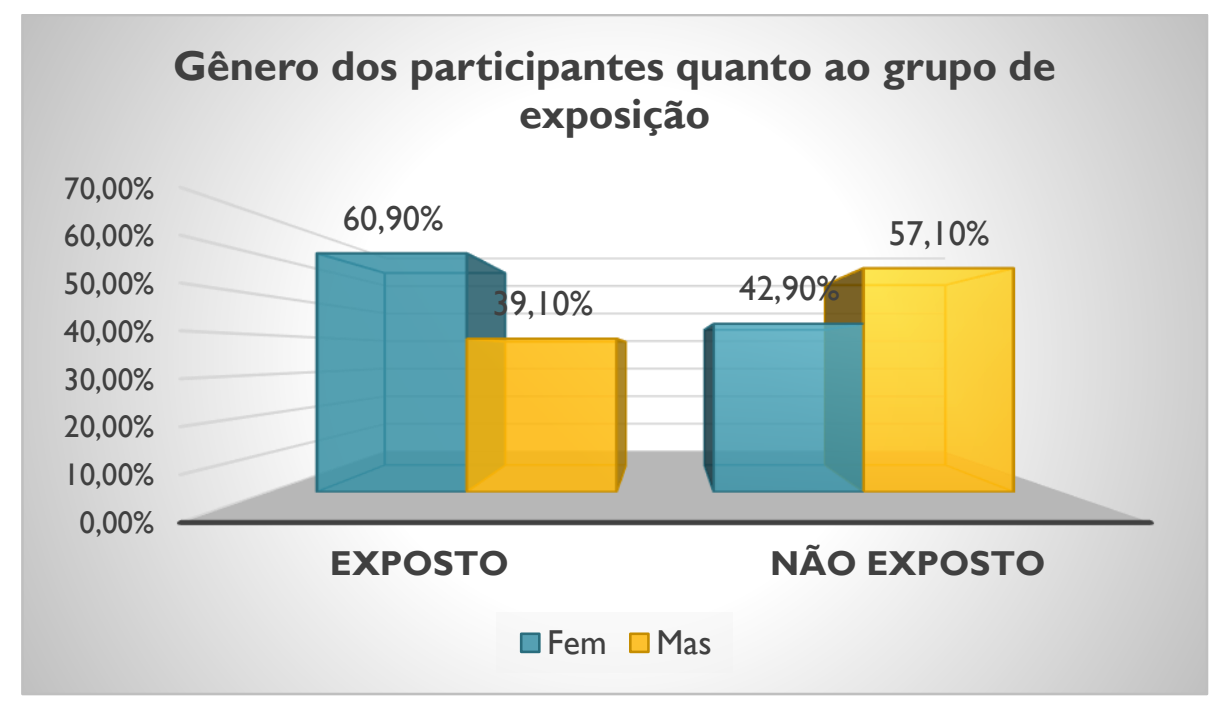

Figura 10 - Distribuição do gênero dos participantes quanto à exposição ao risco

Cerca de $60,9 \%$ dos participantes expostos ao risco eram do sexo feminino e $39,1 \%$ do sexo masculino. Já entre os não expostos, $42,9 \%$ dos participantes eram do sexo feminino e $57,1 \%$ do sexo masculino.

\subsubsection{Idade segundo grupos de exposição}

Buscando analisar a correlação entre a idade e a exposição ao risco, notou-se que a concentração dos participantes continuou entre os 14 e 16 anos, sendo que, em ambos os grupos de exposição ao risco, mais de $70 \%$ dos participantes possuíam idade nesta faixa etária. Também foi possível verificar que há uma maior abrangência na idade dos participantes expostos ao risco e que os não expostos, foram os mais jovens. Os não expostos mostraram idades significativamente menores que os exposto $(p=0,017)$.

No grupo dos participantes expostos ao risco, a idade foi de $M=15,3$ anos $(+-1,3)$ anos e, como já foi possível notar, os participantes do estudo tinham idades entre 13 e 18 anos, sendo estas as idades, mínima e máxima, respectivamente (Figura 9). No grupo dos participantes não expostos ao risco, a 
idade foi de $M=14,4$ anos (+-0,9) e tinham idades entre 13 e 16 anos, sendo as idades mínima e máxima, respectivamente.

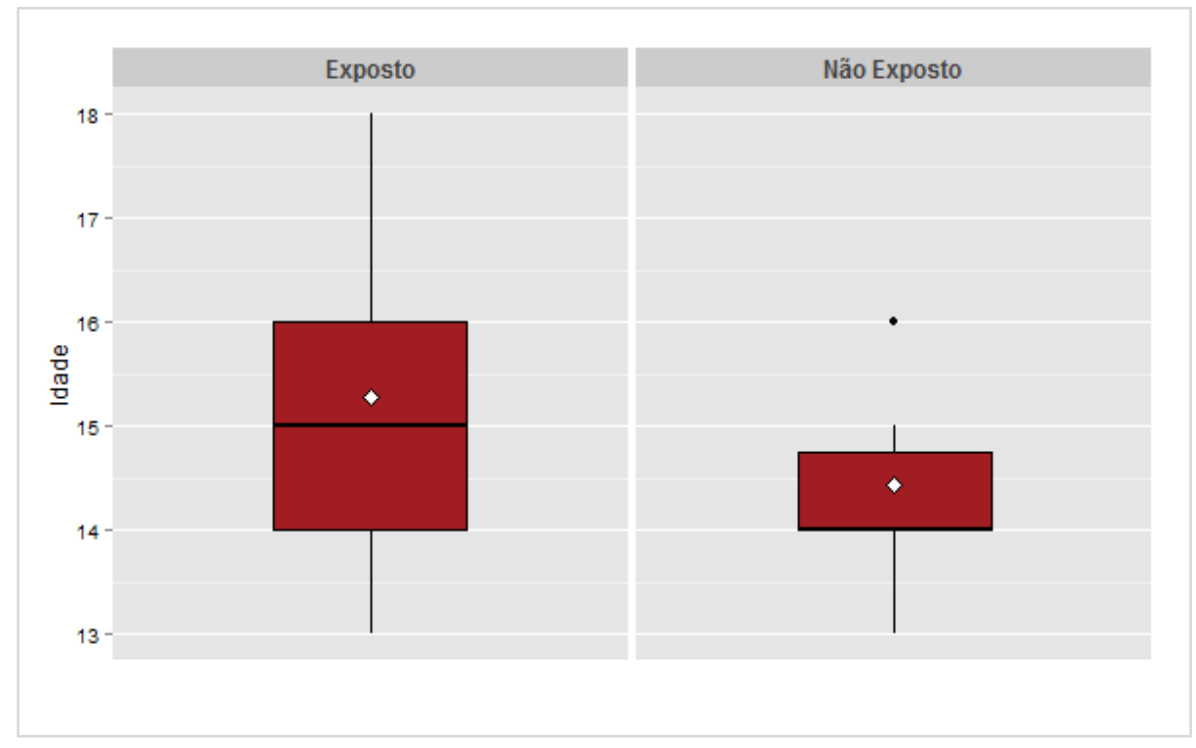

Figura 11 - Boxplot da idade dos participantes segundo exposição

\subsubsection{Emissões Otoacústicas}

Os resultados a seguir estão apresentados por orelha.

\subsubsection{Orelha esquerda}

Analisando as emissões otoacústicas da orelha esquerda, observou-se as médias obtidas separadas por grupo, caso e controle, e subgrupo, exposto ou não exposto.

Na tabela 1, ao observar as respostas das amplitudes e relação $S / R$ da orelha esquerda entre os indivíduos expostos e não expostos do grupo caso, nota-se que, as melhores respostas foram as dos indivíduos não expostos. 
Apesar de não terem tido diferenças estatisticamente significantes, os valores absolutos na maioria das frequências avaliadas, evidenciam respostas relativamente melhores entre os indivíduos não expostos. O mesmo ocorreu no grupo controle, com exceção da frequência de 8 e 10kHz na $S / R$ e de $12 \mathrm{kHz}$ na amplitude.

Tabela 1. Média das amplitudes e relação sinal/ruído para os grupos caso e controle em relação ao exposto e não exposto da orelha esquerda.

\begin{tabular}{|c|c|c|c|c|c|c|c|c|c|c|c|c|}
\hline \multirow{4}{*}{$\begin{array}{l}\text { Frequência } \\
(\mathrm{kHz})\end{array}$} & \multicolumn{12}{|c|}{ Grupos } \\
\hline & \multicolumn{6}{|l|}{ Case } & \multicolumn{6}{|c|}{ Controle } \\
\hline & \multicolumn{2}{|c|}{ Exposto } & \multicolumn{2}{|c|}{ Não exposto } & \multicolumn{2}{|c|}{ P-valor } & \multicolumn{2}{|c|}{ Exposto } & \multicolumn{2}{|c|}{ Não exposto } & \multicolumn{2}{|c|}{ P-valor } \\
\hline & Ampl. & $\mathrm{S} / \mathrm{R}$ & Ampl. & S/R & Ampl. & $\mathrm{S} / \mathrm{R}$ & Ampl. & $\mathrm{S} / \mathrm{R}$ & Ampl. & $\mathrm{S} / \mathrm{R}$ & Ampl. & $\mathrm{S} / \mathrm{R}$ \\
\hline 2 & 5.3 & 14.2 & 11.5 & 21.5 & 0.80 & 0.30 & 8.1 & 16.7 & 10.8 & 16.1 & 0.07 & 1.00 \\
\hline 4 & 2.2 & 18.8 & 4.5 & 24.0 & 0.35 & 0.07 & 4.7 & 21.2 & 5.9 & 22.4 & 0.61 & 0.51 \\
\hline 6 & 3.9 & 20.9 & 4.0 & 19.0 & 0.58 & 0.63 & 5.7 & 25.1 & 4.3 & 21.9 & 0.39 & 0.19 \\
\hline 8 & 10.4 & 17.9 & 6.5 & 21.0 & 0.88 & 0.53 & 6.1 & 24.8 & 3.7 & 16.3 & 0.42 & $0.01^{*}$ \\
\hline 10 & 3.7 & 17.5 & 7.0 & 22.0 & 0.30 & 0.68 & 7.7 & 24.4 & 7.1 & 18.6 & 0.76 & $0.02^{*}$ \\
\hline 12 & 4.2 & 12.9 & 3.5 & 12.5 & 0.56 & 1.00 & 6.7 & 17.8 & 1.3 & 12.9 & $0.01^{*}$ & 0.13 \\
\hline General & 4.7 & 17.5 & 6.1 & 19.8 & 0.36 & 0.24 & 6.5 & 21.7 & 5.7 & 18.0 & 0.40 & $0.00^{*}$ \\
\hline
\end{tabular}

Amp: Amplitude, S/R: sinal/ruído. Teste Qui-quadrado, $p<0.05$; “*”: Refere-se à Frequência em que houve significância.

\subsubsection{Orelha direita}

A tabela 2 foi composta com as médias de amplitude e relação sinal/ruído separadas por grupo, caso e controle, e subgrupo, exposto ou não exposto.

$\mathrm{Na}$ orelha direita, foi observado melhores resultados de relação S/R entre os indivíduos não expostos na maioria das frequências avaliadas, exceto na frequência de $12 \mathrm{kHz}$ em S/R para o grupo controle (Tabela 9). 
Tabela 2. Média das amplitudes e relação sinal/ruído para os grupos caso e controle e exposto e não exposto da orelha direita.

\begin{tabular}{|c|c|c|c|c|c|c|c|c|c|c|c|c|}
\hline \multirow{4}{*}{$\begin{array}{l}\text { Frequência } \\
(\mathrm{kHz})\end{array}$} & \multicolumn{12}{|l|}{ Grupo } \\
\hline & \multicolumn{6}{|l|}{ Caso } & \multicolumn{6}{|c|}{ Controle } \\
\hline & \multicolumn{2}{|c|}{ Exposto } & \multicolumn{2}{|c|}{ Não Exposto } & \multicolumn{2}{|c|}{ P-valor } & \multicolumn{2}{|c|}{ Exposto } & \multicolumn{2}{|c|}{ Não Exposto } & \multicolumn{2}{|c|}{ P-valor } \\
\hline & Ampl. & $\mathrm{S} / \mathrm{R}$ & Ampl. & $\mathrm{S} / \mathrm{R}$ & Ampl. & $\mathrm{S} / \mathrm{R}$ & Ampl. & $\mathrm{S} / \mathrm{R}$ & Ampl. & $\mathrm{S} / \mathrm{R}$ & Ampl. & $\mathrm{S} / \mathrm{R}$ \\
\hline 2 & 8.6 & 16.9 & 8.5 & 19.5 & 0.23 & 0.28 & 9.3 & 15.8 & 9.6 & 17.4 & 0.78 & 0.48 \\
\hline 4 & 3.2 & 19.7 & 1.0 & 21.0 & 0.27 & 0.75 & 6.0 & 21.7 & 5.7 & 23.9 & 1.00 & 0.25 \\
\hline 6 & 4.8 & 23.4 & 1.0 & 20.5 & 0.82 & 0.57 & 6.2 & 23.9 & 6.2 & 24.5 & 0.85 & 1.00 \\
\hline 8 & 6.0 & 19.3 & 6.0 & 16.5 & 0.62 & 0.86 & 4.4 & 20.9 & 5.0 & 20.3 & 1.00 & 0.59 \\
\hline 10 & 6.6 & 18.5 & 11.0 & 26.0 & 0.49 & 0.32 & 8.0 & 23.8 & 10.6 & 20.8 & 0.28 & 0.30 \\
\hline 12 & 1.8 & 13.3 & -2.0 & 14.0 & 0.94 & 0.78 & 5.3 & 19.7 & 3.2 & 14.3 & 0.51 & $0.03^{*}$ \\
\hline General & 5.4 & 18.8 & 4.0 & 19.5 & 0.60 & 0.67 & 6.5 & 20.9 & 6.7 & 20.2 & 0.86 & 0.40 \\
\hline
\end{tabular}

Amp: Amplitude, S/R: sinal/ruído; Teste Qui-quadrado, $p<0.05$; “*”: Refere-se à Frequência em que houve significância.

Nas figuras 12, 1314 e 15, estão representadas as respostas das EOA (amplitude e relação $S / R$ ) por orelha (esquerda e direita) dos expostos do grupo caso e não expostos do grupo controle respectivamente.

Foi observado que, os valores médios de amplitude e relação $S / R$ nos indivíduos não expostos do grupo controle foram maiores que nos expostos do grupo caso. Essas respostas foram observadas em todas as frequências de ambas orelhas exceto em $8 \mathrm{kHz}$ na Amplitude da OE. Contudo houve diferenças estatisticamente significantes na média geral de respostas da relação $S / R$ tanto para orelha esquerda $(p=0,001)$ quanto para orelha direita $(p=0,004)$ e nas frequências seletivas de 2, 4 e $8 \mathrm{kHz}$ na orelha esquerda e 4 e $12 \mathrm{kHz}$ na orelha direita $(p<0,005)$. 


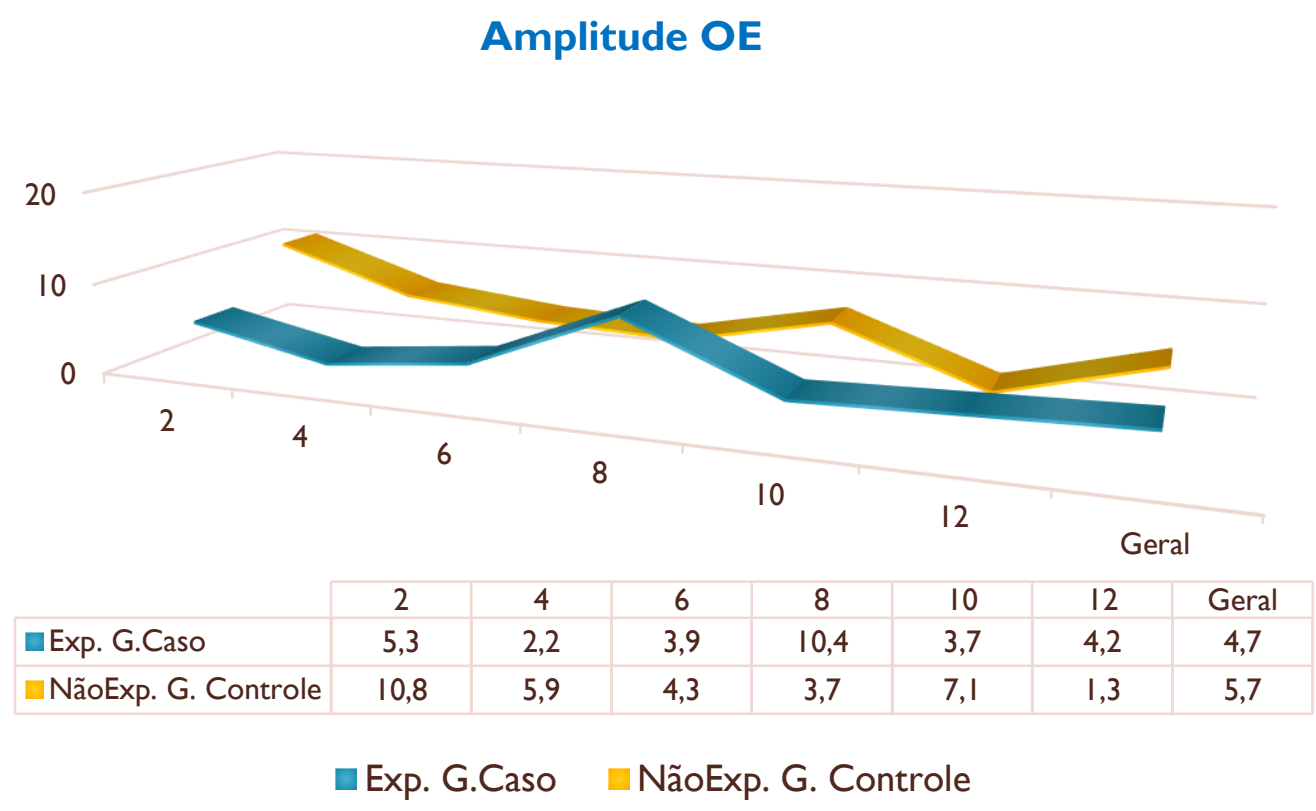

Figura 12 - Comparativo de respostas da amplitude da orelha esquerda por grupos distintos exposto caso e não exposto controle.

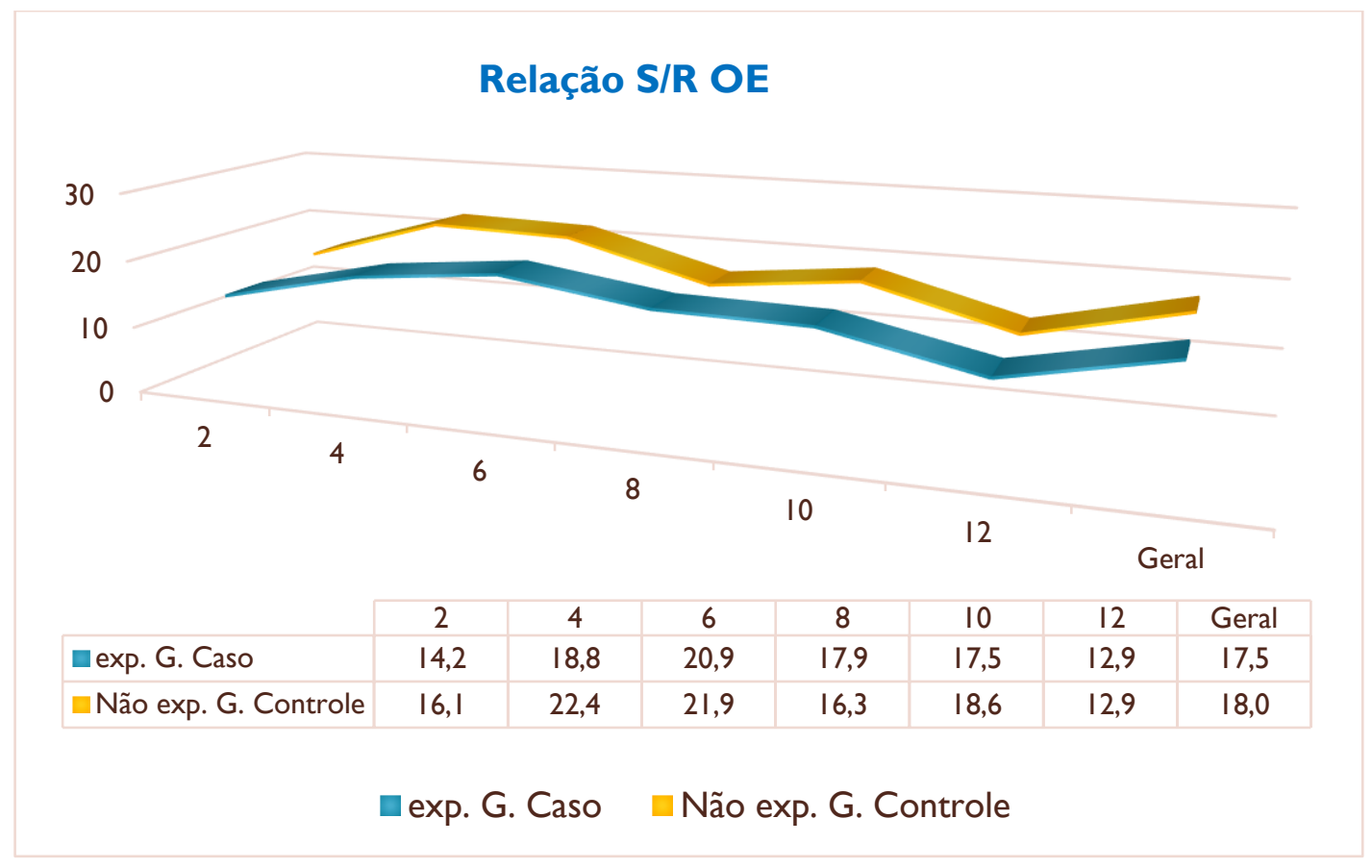

Figura 13 - Comparativo de respostas da relação $S / R$ da orelha esquerda por grupos distintos exposto caso e não exposto controle. 


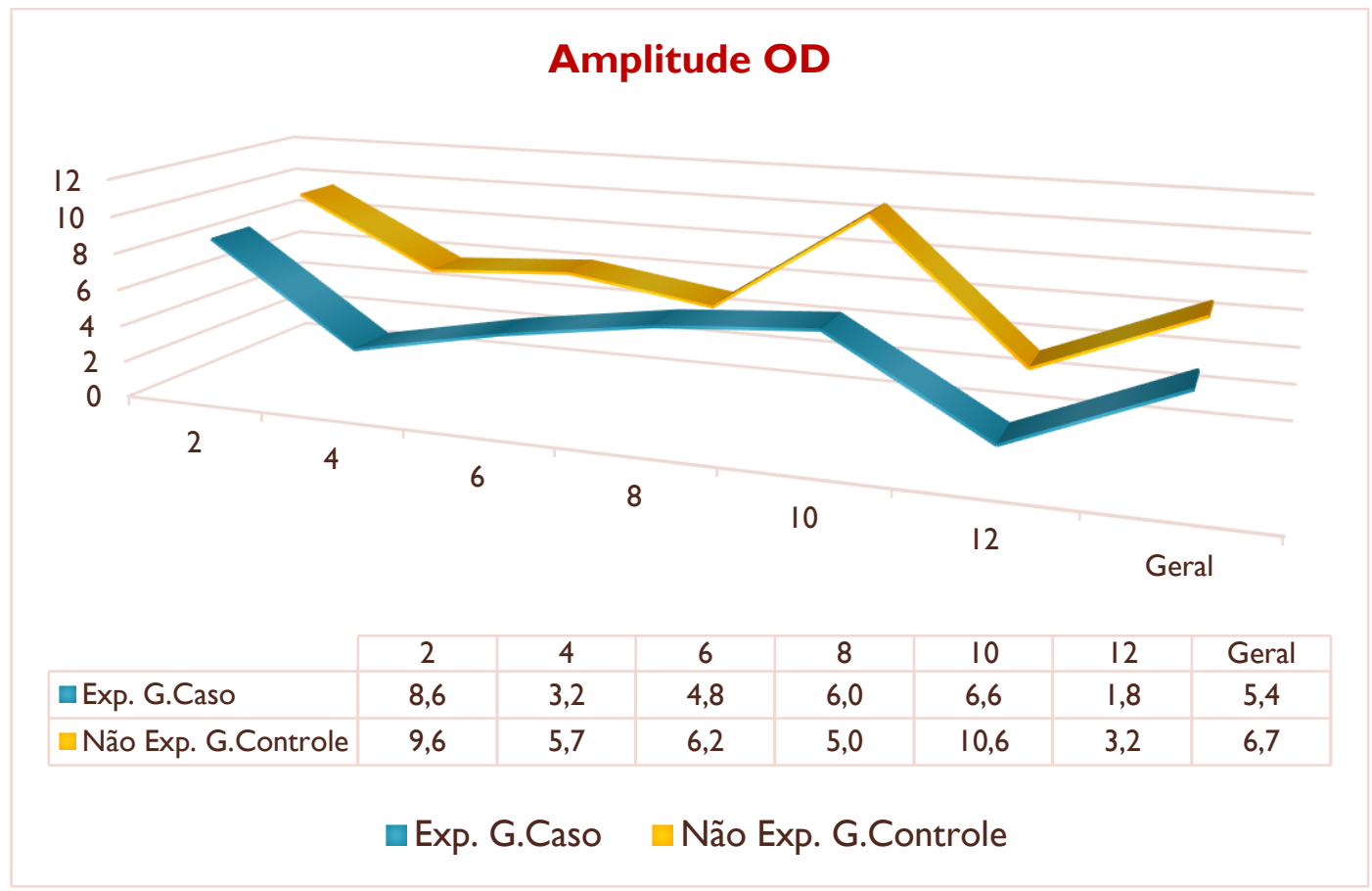

Figura 14 - Comparativo de respostas da amplitude da orelha direita por grupos distintos exposto caso e não exposto controle.

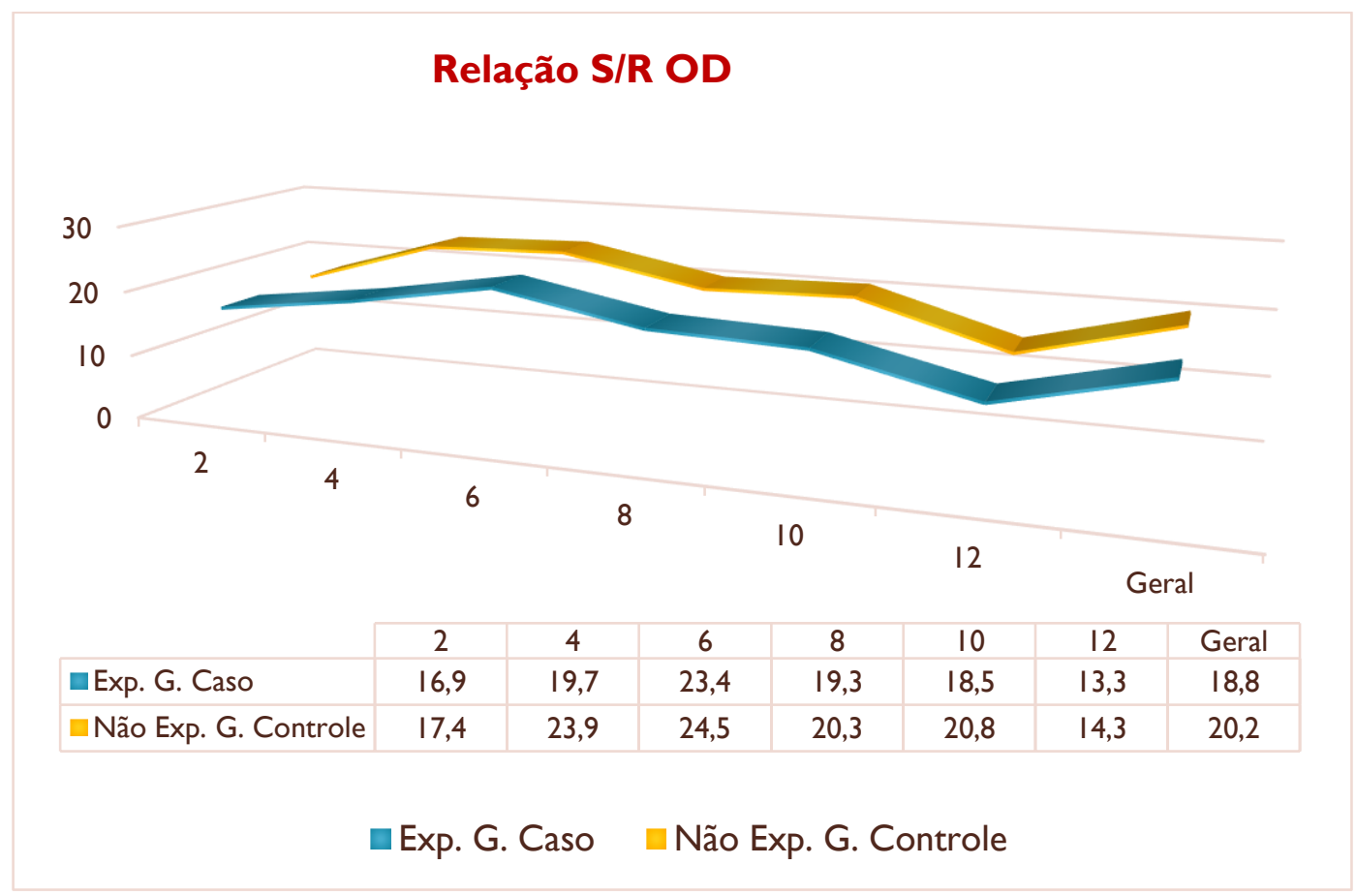

Figura 15 - Comparativo de respostas da relação $S / R$ da orelha direita por grupos distintos exposto caso e não exposto controle. 


\section{4- Análise de Associação - Razão de Chances}

A tabela de contingência (Tabela 11) apresenta a distribuição entre os grupos (caso e controle) e subgrupos (exposto e não exposto).

Foi verificada a associação entre os grupos caso/controle e a exposição à música amplificada, encontrando-se um OR=9.33, com IC95\% 1,65-68,78 e o valor de $p=0,006$ indicando haver uma associação entre a exposição e as alterações nos exames de emissões otoacústicas.

Table 3 - Contigência entre os grupos e subgrupos propostos.

\begin{tabular}{llll}
\hline Grupo/Subgrupo & Caso & Controle & Total \\
\hline Exposto & 28 & 18 & 46 \\
Não exposto & 2 & 12 & 14 \\
Total & 30 & 30 & 60
\end{tabular}

Teste Qui-quadrado, $p=0,006$ 


\section{DISCUSSÃO}

A possibilidade de identificação precoce de uma alteração coclear em sujeitos com audição normal levou diversos pesquisadores ${ }^{86-88}$ a estudarem os efeitos auditivos causados pelo ruído ocupacional, por meio do teste das EOA. A partir dos estudos baseados nos efeitos do ruído ocupacional, vêm se estudando também os efeitos nocivos do ruído de lazer.

Reconhecendo que as EOA podem representar um recurso técnico importante de prevenção das perdas auditivas induzidas por níveis de pressão sonora elevado (PAINPSE), escolheu-se esse instrumento de avaliação auditiva, a fim de estudar as condições cocleares de estudantes do ensino médio, por serem sujeitos com maior probabilidade de apresentarem hábitos que os colocam num grupo de risco para a perda auditiva.

\subsection{Estudo das Emissões Otoacústicas Produto de Distorção}

Na literatura pesquisada, foi encontrado um número reduzido de estudos relativos às EOAPD em altas frequências em jovens desta faixa etária, o que pode levar nosso trabalho a ser referência neste aspecto de variável. Portanto, os resultados discutidos foram comparados aos dados de normalidade de trabalhos desenvolvidos com foco maior na exposição a ruído ocupacional em sujeitos de maior idade, além daqueles que tratam da população equivalente à deste trabalho.

Alguns autores $32,52,59$ já fizeram referência à sensibilidade das EOA por estímulo transiente em detectar alterações sutis na cóclea, advindas da exposição ao ruído. Fiorini e Fischer $(2004)^{62}$ relataram que a presença de EOAT indica que a maioria dos limiares está dentro do padrão de normalidade e por outro lado, a sua ausência, pode indicar um comprometimento inicial das CCE. A casuística do presente estudo foi composta por jovens com audição normal, avaliados pelo exame padrão (audiometria tonal limiar). A avaliação da sensibilidade das EOAT, portanto, não foi realizada, por se tratar de um teste com pouca especificidade de frequência. A legislação (PORTARIA n. 19/1998, 
DO MINISTÉRIO DO TRABALHO) ${ }^{29}$ reconheceu que as alterações cocleares provocadas pela exposição ao ruído atingem, no início, especificamente a faixa das frequências altas. Dessa forma, um teste auditivo que possibilitasse a investigação da integridade tonotópica coclear, abrangendo as altas frequências, teria relevância no monitoramento ocupacional. Por isso, as EOAPD são o tipo de teste mais utilizado em pesquisas relacionadas à exposição ao ruído $28,41,56,86,87$. Portanto, a seguir serão comentados os achados referentes aos resultados para amplitude do sinal e relação sinal/ruído das EOAPD.

Primeiramente, é importante ressaltar que, na literatura pesquisada, não foram encontrados trabalhos com EOAPD em altas frequências (acima de 8 $\mathrm{KHz}$ ). Por isso, serão discutidos apenas os resultados a partir dos dados obtidos até $8 \mathrm{KHz}$, com análises da amplitude e da relação sinal/ruído das EOAPD dos dois grupos: caso e controle.

\subsection{Análise dos resultados das EOAPD}

De acordo com o critério "Passa/Falha" estabelecido na presente pesquisa para separar os participantes em grupos - caso ou controle, foi observado nos resultados um maior número de resultados "Passa" na orelha direita $(70 \%)$ em comparação a orelha esquerda (65\%). Tal resultado também foi observado na média das amplitudes absolutas e na relação $S / R$ do lado direito em relação ao esquerdo. Na relação $S / R$ da orelha direita, as médias variaram entre de 13,3 e 26,0dBNPS e para a orelha esquerda, entre 12,5 e 25,1 dBNPS, estando as maiores médias concentradas no grupo de não expostos. Comparando nossos resultados com demais estudos 9,10,19, em média, as respostas encontradas foram menores que as nossas, compreendendo a faixa entre 10 e 15dBNPS em grupos sem exposição, e entre 5 e 15dBNPS em grupos expostos ao ruído.

Esta diferença não foi estatisticamente significante, porém, este achado pode estar relacionado ao mesmo fenômeno que ocorre nas emissões por transiente. As amplitudes são maiores na orelha direta e no sexo feminino, por influência das EOA espontâneas, pois, as respostas tendem a desaparecer quando essas diferenças são corrigidas. Ao compararmos os dois subgrupos do 
nosso estudo, exposto e não exposto (Tabelas 8, 9 e 10), notou-se que houve dominância de melhores respostas das amplitudes na orelha direita, principalmente no subgrupo dos não expostos, que tiveram respostas ainda melhores.

Apesar de mostrar a prevalência de resultados "Passa" ou "Falha" não ter sido o foco deste estudo, evidenciou-se na amostra estudada, maior prevalência de participantes caracterizados como caso, ou seja, com resultado "Falha" na EOAPD. Tal fato levou à necessidade de uma exclusão de 26 indivíduos do grupo caso para uma melhor comparação estatística entre os grupos. Em outro estudo realizado pelo nosso grupo ${ }^{3}$, que utilizou parâmetros semelhantes aos do presente trabalho, também foi verificada maior prevalência de exames "Falha", ao analisar a ocorrência de EOAPD em sujeitos expostos à música alta. Outro estudo $^{9}$ encontrou percentuais mais elevados de normalidade que os verificados neste estudo, porém, não foi relatado com precisão o critério de avaliação adotado pelos autores. Além disso, os autores utilizaram frequências mais baixas que as do presente estudo, podendo justificar o maior número de alterações, justamente nessas bandas de frequências. Tais achados podem indicar de forma precoce, uma disfunção coclear.

Estudo $^{69}$ com adolescentes revelou um percentual significativo de alterações (63\%). As diferenças de percentuais, na comparação dos achados com os estudos aqui citados, podem possivelmente estar relacionadas às divergências metodológicas. Acredita-se que o número elevado de "Falha" do atual trabalho possa estar relacionado também ao critério metodológico mais rigoroso, além da avaliação com altas frequências.

Examinando ainda os resultados das mesmas tabelas 1 e 2 por grupo de exposto e não exposto, observou-se uma relação inversamente proporcional entre amplitude e frequência, ou seja, uma tendência de redução nos valores das amplitudes conforme o aumento das frequências avaliadas, porém não houve diferença estatisticamente significante $(p>0,05)$. Quanto maior foi a frequência avaliada, menores foram os valores de amplitudes observados também em outros estudos, mesmo utilizando equipamentos diferentes $3,6,9,61,86,89$.

Neste estudo, de modo geral, as médias das amplitudes das orelhas direitas foram maiores que as da orelha esquerda e pode também estar 
relacionado à influência das EOA espontâneas como já mencionado anteriormente. Ao analisar as orelhas esquerda e direita dos grupos, os valores das amplitudes nas bandas de frequências de 8 e $12 \mathrm{KHz}$ foram significativamente menores do que as amplitudes das demais frequências. $\mathrm{Na}$ frequência de $8 \mathrm{KHz}$, a resposta não é boa porque nessa frequência, a necessidade de um alto falante com maior voltagem pode aumentar a distorção ${ }^{26}$. É provável que este mesmo efeito possa ter acontecido com a frequência de $12 \mathrm{KHz}$. Estes achados corroboram com os encontrados em nosso último estudos ${ }^{3}$ que também analisou altas frequências, com resultados semelhantes.

Apesar de não terem sido encontradas outras justificativas para esse fato, não se considera esta resposta como um dado aleatório. Propõe-se que novos estudos sejam realizados para investigação de possíveis registros das amplitudes absolutas das EOAPD, utilizando altas frequências (acima de $8 \mathrm{KHz}$ ).

Os resultados encontrados entre os grupos estudados não foram estatisticamente significantes em todas as frequências avaliadas. Contudo elas sinalizam, em maior ou menor grau, um prognóstico de suscetibilidade para perdas auditivas. Considerou-se a hipótese de que os baixos valores de amplitude observados nas altas frequências possam ser sugestivos de uma cocleopatia subclínica. Pode-se considerar a hipótese de que tais regiões cocleares já tenham sido afetadas pelo ruído ${ }^{18}$.

As supostas alterações de CCE encontradas nos exames de EOAPD, porém, não foram suficientes para alterar os limiares audiométricos. Esses dados são justificados por autores ${ }^{25,90}$ que relataram ser a avaliação audiométrica insuficiente para determinar o estado funcional das CCE; pois lesões de até $30 \%$ das CCE, com células ciliadas internas (CCl) íntegras, podem ocorrer antes que qualquer perda auditiva seja detectada. Portanto, as EOA são eficientes para avaliar precocemente a função coclear (CCE) em sujeitos expostos à ruído, sem que tenha sido diagnosticada alguma perda auditiva. Sugere-se que esse exame seja acrescentado na rotina clínica para complementar o diagnóstico de PAINEPS também em jovens adolescentes. 


\subsection{Divergências Metodológicas}

Neste estudo, considerou-se a amplitude absoluta das EOAPD quando os NPS atingiram um valor igual ou maior que $-5 \mathrm{dBNPS}$, sendo o mesmo utilizado por Silva et al. ${ }^{3}$. O trabalho de Uchida et al. ${ }^{57}$, realizado com EOA, teve como referência para amplitude absoluta de EOAPD o valor mínimo de -20dB NPS. Já o de Maia e Russo ${ }^{91}$ avaliou somente relação sinal/ruído encontrando valores mais baixos que os nossos e acredita-se que os resultados deste estudo tenham sido elevados, em comparação à literatura consultada, devido à diferença de equipamento e protocolo.

Foi possível notar que houve proximidade de resultados deste estudo apenas com o ultimo realizado por nós ${ }^{3}$, que utilizou os mesmos parâmetros. Supõe-se então, que a realização de mais estudos com os mesmos padrões de avaliação, podem nos direcionar a uma padronização de protocolos para avaliação de jovens expostos à ruído não ocupacional, assim como já existe para os neonatos nas EOATE. Ratifica-se ainda que, nossos dados referentes à amplitude e relação $S / R$, possam servir como base para pesquisas que venham a utilizar o mesmo equipamento em indivíduos jovens.

Constatou-se então, ao se confrontar os resultados que a ocorrência de alterações pode apresentar grande variabilidade. Supõe-se que essa diversidade possa estar relacionada aos aspectos metodológicos, aos parâmetros utilizados e aos critérios selecionados para análise. Outros autores 41,55,62 fizeram referência à variedade dos resultados encontrados nas EOA, em decorrência da falta de padronização universal desse teste. Dessa forma, ressalta-se que mais pesquisas sejam realizadas, com o mesmo equipamento, para aferir os resultados.

\subsection{Exposição dos Jovens à Música Amplificada}

Já foi relatado, em pesquisas anteriores, que aqueles indivíduos com histórico de uso de fone de ouvido em circunstâncias ruidosas, ou os mais expostos, apresentaram limiares auditivos mais elevados, em comparação com os participantes sem um histórico de uso do fone de ouvido ou menos expostos 
a ruído 7,11,71,92. A exposição sonora não ocupacional tem sido cada vez mais estudada e despertado preocupação para a comunidade científica. Estudo ${ }^{93}$ aponta que o ruído não ocupacional oferece menor risco de causar lesão, porém o número de jovens que se expõem a esse tipo de ruído; particularmente, o fone de ouvido é bastante expressivo.

Verificou-se, no presente trabalho, que a maioria dos participantes do grupo caso apresentou mais idade quando comparados aos do grupo controle ( $\mathrm{p}=0,017$ ); o que nos levou a intuir que os indivíduos mais velhos estão mais susceptíveis a apresentar alterações cocleares. A chance dos participantes com alterações cocleares terem sido expostos à música amplificada foi de 9.33 vezes (OR) maior que os sem alterações cocleares.

Nesta pesquisa, o levantamento feito da exposição dos adolescentes à música amplificada sugere que a cultura atual da juventude parece ser de não se preocupar com os efeitos nocivos da música alta. Ao responderem o questionário referente ao hábito de usar fones de ouvido e de frequentar lugares com música amplificada, a maioria dos jovens assinalou ter esse hábito, fato que levou à inclusão no subgrupo de expostos (Tabela 11). Não têm preocupação com a exposição prolongada nem com o volume excessivo do som, comportamentos que os expõem a lesões cocleares precoces e irreversíveis ${ }^{94}$. $\mathrm{Na}$ Holanda, $70 \%$ dos jovens relataram frequentar danceterias e $24,6 \%$ apresentam risco para a perda auditiva pela exposição estimada a 100 dBA por mais de uma hora por semana, sem o uso de proteção auditiva ${ }^{95}$.

A música é um som prazeroso ao ser humano, contudo possui potencial para ser considerado como um som agressor. Os sons vinculados ao lazer, como a música, apesar de serem menos prejudiciais, não deixam de ser, atualmente, um fator de risco para perdas auditivas. Segundo o guia para ruído urbano da $\mathrm{OMS}^{95}$, há uma preocupação com os jovens que frequentam ambientes como festas, boates, concertos, cinemas e eventos ao ar livre, pois há exposição a níveis altos de intensidade $(100 \mathrm{~dB})$ que podem gerar problemas auditivos. No presente trabalho, foram questionados somente os hábitos de usar o fone de ouvido ou de frequentar lugares com música amplificada. Outros estudos que abordaram outros tipos de hábitos auditivos da população jovem sinalizaram que o hábito de escutar música utilizando fones de ouvido é o mais frequente entre os jovens ${ }^{71,92,96,97}$. Os resultados encontrados neste estudo possivelmente 
refletem a falta de conscientização dos jovens sobre a problemática deste tipo de ruído e seus efeitos.

A PAIR é um problema invisível, que pode estar sendo ignorado pela população jovem quando se trata da música de alta intensidade, e passível de prevenção. Com o apoio das escolas e de programas educativos, esse agente poderia ser minimizado. Além das alterações cocleares mínimas apresentadas neste estudo, há outros prejuízos à audição que pode se manifestar nesta população como o zumbido, por exemplo, que tem sido uma queixa muito frequente entre a população de modo geral94,98,99,100. Os jovens devem ser informados cada vez mais cedo a respeito dos riscos para a audição quando são submetidos à exposição a músicas de alta intensidade ${ }^{100,101}$, seja por meio do uso de fones ou em atividades de lazer que envolvam música amplificada.

Atitudes que podem minimizar esses maus hábitos envolvem fiscalização de níveis de intensidades para ambientes com música, abordagem de questões relacionadas a hábitos auditivos saudáveis como parte dos currículos escolares, desde as séries mais iniciais, a solicitação de exames audiológicos periódicos anuais como rotina clínica de pediatras, hebiatras e otorrinolaringologistas, a fim de monitorar a audição e prevenir prejuízos maiores. Diante disso, torna-se relevante um trabalho de conscientização dos prejuízos que esse tipo de exposição pode acarretar. 


\section{CONCLUSÃO}

O estudo mostrou que os participantes com alterações nos exames das emissões otoacústicas, foram significativamente mais expostos à música amplificada o que indica, associação entre os sinais de comprometimento das células cocleares nesse grupo de indivíduos e a exposição sonora.

Referente à análise dos resultados das EOAPD, tanto na amplitude do sinal quanto na ralação $S / R$, as médias de respostas dos sujeitos não expostos foram melhores quando comparadas aos expostos.

Pela análise da Razão de Chances (OR), aqueles que foram expostos tiveram 9.33 vezes mais chance de terem apesentado alterações nas células ciliadas externas em relação àqueles que não foram expostos. 


\section{REFERÊNCIAS}

1. Jofré D, La Paz F, Platzer L, Anabalón JL, Grasset EE, Barnafi NN. Evaluación de la exposición a ruído social en jóvenes chilenos. Rev. Otorrinolaringol. Cir. Cabeza Cuello. 2009; 69: 23-28.

2. Keppler H, Dhooge I, Maes L, D'Haenens W, Bockstael A, Philips B, et al. Short-term auditory effects of listening to an MP3 player. Arch Otolaryngol Head Neck Surg [Research Support, Non-U.S Gov't] 2010;136:538-48.

3. Silva VG, Sampaio, ALL, Oliveira CACP, Tauil PL, Jansen GMB. Hair cell alteration prevalence rates in students of a school in Distrito Federal. Braz $\mathrm{J}$ Otorhinolaryngol. 2012;78(4):91-7.

4. McCreery RW, Venediktov RA, Coleman JJ, Leech HM. An evidence-based systematic review of directional microphones and digital noise reduction hearing aids in school-age children with hearing loss. American Journal of Audiology. 2012;21:295-312.

5. Sánchez YG, Díaz YF. Efectos de la contaminación sónica sobre la salud de estudiantes y docentes, en centros escolares. Revista Cubana de Higiene y Epidemiología. 2014;52 (3):402-10.

6. Sanchez TG, Oliveira JC, Kii MA, Freire K, Cota J, Moraes FV. Zumbido em adolescentes: o início da vulnerabilidade das vias auditivas CoDAS 2015;27(1):5-12.

7. Martinez-Wbaldo MC, Soto-Vázquez C, Ferre-Calacich I, Zambrano-Sánchez E, Noguez-Trejo L, Lúcia PA. Sensorineural hearing loss in high school teenagers 
in Mexico City and its relationship with recreational noise. Cad. Saúde Púb. 2009;25(12): 2553-61.

8. Luz TS, Borja ALVF. Sintomas auditivos em usuários de estéreos pessoais. Int. Arch. Otorhinolaryngol. 2012;16(2):163-9.

9. Barcelos DD, Dazzi NS. Efeitos do MP3 Player na audição. Rev. CEFAC. 2014;16(3):779-791.

10. Melo T. Perfil audiológico de jovens usuários de dispositivos de escuta pessoal. Distúrb Comum. 2014;26(2): 337-47.

11. Farfán IG, Luján LA, Hernández SL. Correlación de test sobre exposición a ruido yhallazgos audiológicos evaluados en niños y adolescentes mexicanos. An Med (Mex) 2008;53(3):143-8.

12. Mendes MH, Morata TC. Exposição profissional à música: uma revisão. Rev. Soc. Bras. Fonoaudiol. 2007;12(1):63-9.

13. Maia JRF, Russo ICP. Estudo da audição de músicos de rock and roll. PróFono Rev. Atualiz. Cient. 2008;20(1):49-54.

14. Rowool VW, Wayne LAC. Auditory lifestyles and beliefs related to hearing loss among college students in the USA. Noise e Health. 2008;10(38):1-10.

15. Santos I, Colella-Santos MF, Couto CM. Sound pressure level generated by individual portable sound equipment. Braz J Otorhinolaryngol. 2014;80(1):41-7. 
16. Bevilacqua MC, Martinez MAN, Balen SA, Pupo AC, Reis ACM, Frotas S. Tratado de Audiologia. São Paulo: Santos; 2011:145-58.

17. Lee JS, Choi HG, Jang JH, Sim S, Hong SK, Lee HJ, Park B, Kim HJ. Analysis of Predisposing Factors for Hearing Loss in Adults. J Korean Med Sci. 2015;30(8):1175-82.

18. MINISTÉRIO DO TRABALHO. Portaria n. 19, de 09/04/1998 - Diretrizes e Parâmetros Mínimos para Avaliação e Acompanhamento da Audição em Trabalhadores Expostos a Níveis de Pressão Sonora Elevados.

19. Gonçalves CL, Dias FAM. Achados audiológicos em jovens usuários de fones de ouvido. Rev. CEFAC. 2014;16(4):1097-1108.

20. Almeida-Filho N, Filletti F, Guillaumon HR, Serafini F. Intensidade do ruído produzido em sala de aula e análise de emissões acústicas em escolares. Arq. Int. Otorrinolaringol. 2012;16(1):91-5.

21. Guida HL, Sousa AL, Cardoso ACV. Relação entre os achados da avaliação audiométrica e das emissões otoacústicas em policiais militares. Arq. Int. Otorrinolaringol. 2012;16(1):67-73.

22. Figueiredo RR, Azevedo AA, Oliveira PM, Amorim SPV, Rios AG, Baptista V. Incidence of tinnitus in $\mathrm{mp} 3$ player users. Braz $\mathrm{J}$ Otorhinolaryngol. 2011;77(3):293-8.

23. Hanazumi A, Gil D, Maria Cecília Martinelli lório MCM. Estéreos pessoais: hábitos auditivos e avaliação audiológica. ACR. 2013;18(3):179-85. 
24. Bento RF, Martins GSQ, Pinna M. Tratado de otologia. São Paulo: Atheneu; $2^{\mathrm{a}}$ ed. 1998. p.107-16.

25. Momensohn-Santos TM e Russo ICP. Prática da audiologia clínica. $7^{\underline{a}}$ ed. São Paulo: Cortez; 2009. p. 23-44.

26. Azevedo MF. Emissões otoacústicas. In: Figueiredo MS. Emissões Otoacústicas e BERA. São Paulo: Pulso; 2003. p.35-83.

27. Comitê Nacional de Ruído e Conservação Auditiva. Arquivos Internacionais de Otorrinolaringologia. vol. 4, n. 2, abr/jun, 2000.

28. Marques FP, Costa EA. Exposição ao ruído ocupacional: alteração no exame de emissões otoacústicas. Braz J Otorhinolaryngol. 2006;72(3): 362-6.

29. MINISTÉRIO DO TRABALHO. Portaria n. 19, de 09/04/1998 - Diretrizes e Parâmetros Mínimos para Avaliação e Acompanhamento da Audição em Trabalhadores Expostos a Níveis de Pressão Sonora Elevados.

30. Rocha EB, Azevedo MF, Ximenes FJA. Estudo da audição de crianças de gestantes expostas ao ruído ocupacional: avaliação por emissões otoacústicas produto de distorção. Braz J Otorhinolaryngol. 2007;73(3): 359-69.

31. Mendes MH, Morata TC. Exposição profissional à música: uma revisão. Rev. Soc. Bras. Fonoaudiol. 2007;12(1): 63-9.

32. Barros SMS, Frota S, Atherino CCT, Osterne F. A eficiência das emissões otoacústicas transientes e audiometria tonal na detecção de mudanças 
temporárias nos limiares auditivos após exposição a níveis elevados de pressão sonora. Braz J Otorhinolaryngol. 2007;73(5): 592-8.

33. Bouccara D, Ferrary E, Sterkers O. Effects of noise on inner ear. Med. SCi (Paris). 2006;22(11): 979-84.

34. Bezerra MD, MarquesR. A. Configurações audiométricas em saúde ocupacional. RBPS. 2004;17(2): 61-5.

35. Pfeiffer M, Rocha RLO, Oliveira FR, Frota S. Intercorrência audiológica em músicos após um show de rock. Rev. CEFAC. 2007;9(3): 423-9.

36. Serra MR, Biossoni EC, Hinalaf M, Pavlik M, Villalobo JP. Program for the Conservation and Promotion of Hearing Among Adolescents. Amer. Jour. of Audiol. 2007;16(2): 158-64.

37. Gonçalves MS, Tochetto TM, Gambini C. Hiperacusia em músicos de banda militar. Rev. Soc. Bras. Fonoaudiol; 2007;12(4): 298-303.

38. Dias A, Cordeiro R, Corrente JE, Gonçalves CGO. Associação entre perda auditiva induzida pelo ruído e zumbidos. Cad. Saú. Púb. 2006;22(1): 63-8.

39. Wazen SRG, Russo ICP. Estudo da audição e dos hábitos auditivos de jovens do Município de Sorocaba - São Paulo. Pro-Fono Rev. de Atual. Cient. 2004;16(1): 83-94.

40. Torre P, Howell JC. Noise levels during aerobics and the potencial effects on distortion product otoacoustic emissions. J Commun Disord. 2008;41(6): 501-11. 
41. Frota S, lório MCM. Emissões otoacústicas por produtos de distorção e audiometria tonal liminar: estudo da mudança temporária do limiar. Braz $\mathrm{J}$ Otorhinolaryngol. 2002;68(1):15-20.

42. Davis B, Qiu W, Hamernik RP. Sensitivity of distortion product otoacoustic emissions in noise-exposed chinchillas. J Am Acad Audiol. 2005;16(2):69-78.

43. Nodarse EM. Empleo de las emisiones otoacústicas para el pesquisaje del deficit auditivo. Rev. Habanera Cienc. Méd. 2006;5(1):1-8.

44. Sousa LCA, Piza MRT, Alvarenga KF, Cóser PL. Eletrofisiologia da audição e emissões otoacústicas: princípios e aplicações clinicas. Ribeirão Preto: Editora Novo Conceito; $2^{\mathrm{a}}$ ed. 2010. p.109-30.

45. Costa JMD. Emissões otoacústicas evocadas por estímulo transiente e por produto de distorção em recém-nascidos prematuros [dissertação]. Brasília. (DF): Faculdade de Medicina. Universidade de Brasília; 2007.

46. Souza DV. Estudo comparativo das emissões otoacústicas evocadas em militares expostos e não expostos ao ruído [dissertação]. Rio de Janeiro (RJ): Universidade Veiga de Almeida; 2009.

47. Muniz L, Caldas N, Caldas NS, Lewis DR, Dóris R, Lessa F. Estudo das amplitudes das emissões otoacústicas em indivíduos exposto ao ruído de trios elétricos. An. Faculdade de Medicina da Universidade Federal de Pernambuco. 2001;46(1): 28-31.

48. Pialarissi PR, Gattaz G. Emissões otoacústicas: conceitos básicos e aplicações clínicas. Rev Arq. da Fund. Otorrinolaringol. 1997;1(2):13-6. 
49. Bosseto MCA, Brock B, Wajnsztojn R. Neonatologia: um convite à atuação fonoaudiológica. São Paulo: Lovise; 1998. p.289-93.

50. Vasconcelos RM, Serra LSM, Aragão VMF. Emissões otoacústicas evocadas transientes e por produto de distorção em escolares. Braz J Otorhinolaryngol. 2008;74(4):503-7.

51. Ikino CMY, Bittar RSM, Sato KM, Capella NM. Hidropsia endolinfática experimental sob ação de inibidor do óxido nítrico sintase tipo II: avaliação com emissões otoacústicas e eletrococleografia. Braz $\mathrm{J}$ Otorhinolaryngol. 2006;72(2):151-7.

52. Momensohn-Santos TMM, Russo ICP, Assayag FM, Lopes LQ. Determinação dos limiares tonais por via aérea e por via óssea. In: MomensohnSantos TMM, Russo ICP, organizadores. Prática da audiologia clínica. 6ª ed. São Paulo: Cortez; 2007. p. 67-95.

53. Wagner W, Heppelmann G, Vonthein R, Zenner HP. Test-retest repeatability of distortion product otoacoustic emissions. Ear Hear. 2008;29(3):378-91.

54. Carvallo RMM, Sanches SGG, Ravagnani MP. Amplitude of transient and distortion product otoacoustic emissions, in young and elderly people. Braz $\mathrm{J}$ Otorhinolaryngol. 2000;66(1):38-45.

55. Vono-Coube CZ, Costa Filho OA. Emissões otoacústicas: uma visão geral. In: Frota S. Fundamentos em Fonoaudiolgia - Audiologia. Rio de janeiro: Guanabara Koogan; 2003. p.95-106. 
56. Fiorini AC, Parrado-Moran MES. Emissões otoacústicas - produto de distorção: estudo de diferentes relações de níveis sonoros no teste em indivíduos com e sem perdas auditivas. Dist. da Comun. 2005;17(3): 385-96.

57. Oeken J, Lenk A, Bootz F. Influence of age and presbyacusis on DPOAE. Acta Otolaryngol. 2000;120(3):396-403.

58. Uchida $Y$, Ando F, Shimokata H, Sugiura S, Ueda H, Nakashima T. The effects of aging on distortion-product otoacoustic emissions in adults with normal hearing. Ear \& Hearing. 2008;29(2):176-84.

59. Barboni M, Geralde AT, Goffi-Gomez MVS, Schultz C, Liberman PHP. Variação teste-reteste da amplitude das emissões otoacústicas transientes evocadas em indivíduos normais. Arq. Int. de Otorrinolaringol.2006;10(2):11924.

60. Gattaz G, Ruggieri M, Bogar P. Estudo das Emissões Otoacústicas Evocadas em Adultos Jovens Audiologicamente Normais. Braz J Otorhinolaryngol. 1994;60(1):15-8.

61. Oliveira TMT, Vieira MM, Azevedo MF. Emissões otoacústicas em trabalhadores normo-ouvintes expostos ao ruído ocupacional. Pró-Fono Rev. de Atual. Cient. 2001;13(1):17-22.

62. Fiorini AC, Fischer FM. Expostos e não expostos a ruído ocupacional: estudo dos hábitos sonoros, entalhe audiométrico e teste de emissões otoacústicas evocadas por estímulos transientes. Dist. da Comun. 2004;16(3): 371-83. 
63. Negrão MA, Soares E. Variações nas amplitudes de respostas das emissões otoacústicas evocadas e suscetibilidade à perda auditiva induzida por ruído PAIR. Rev. CEFAC. 2004;6(4):414-22.

64. Hotz MA, Probst R, Harris FP, Hauser R. Monitoring the Effects of Noise Exposure Using Transiently Evoked Otoacustic. Acta Otolaryngol. 1993;113(3): 478-82.

65. Andrade AIA, Russo ICP, Lima MLLT, Oliveira LCS. Avaliação auditiva em músicos de frevo e maracatu. Braz J Otorhinolaryngol. 2002;68(5): 714-20.

66. Martins JPF, Magalhães MC, Sakae TM, Magajewski FRL. Avaliação da perda auditiva induzida por ruído em músicos de Tubarão-SC. Arq. Catarin. de Med. 2009;38(1): 69-74.

67. Weichbold V, Zorowka P. Can a hearing education campaign for adolescents change their music listening behavior? Int. Jour. of Audiol. 2007;46(3): 128-33.

68. Rowool VW, Wayne LAC. Auditory lifestyles and beliefs related to hearing loss among college students in the USA. Noise Health. 2008;10(38):1-10.

69. Fissore L, Jannelli A, Casaprima V. Exploración auditiva en adolescentes mediante el uso de otoemisiones acústicas. Arch. Argent. Pediatr. 2003;101(6): 448-53.

70. Martinez-Wbaldo MC, Soto-Vázquez C, Ferre-Calacich I, Zambrano-Sánchez E, Noguez-Trejo L, Lúcia PA. Sensorineural hearing loss in high school teenagers in Mexico City and its relationship with recreational noise. Cad. Saúde Púb. 2009; 25(12): 2553-61. 
71. Lacerda ABM, Gonçalves VGO, Zocoli AMF, Dias C, Paula K. Hábitos auditivos e comportamento de adolescentes diante das atividades de lazer ruidosas. Rev. CEFAC. 2011;13(2):322-9.

72. Silveira JAM, Brandão ALA, Rossi JFLLA, Name MAM, Estefan P, Gonçalez F. Avaliação da alteração auditiva provocada pelo uso do walkman, por meio da audiometria tonal e das emissões otoacústicas (produtos de distorção): estudo de 40 orelhas. Braz J Otorhinolaryngol. 2001;67(5):650-4.

73. Farfán IG, Luján LA, Hernández SL. Correlación de test sobre exposición a ruido yhallazgos audiológicos evaluados en niños y adolescentes mexicanos. An Med (Mex). 2008;53(3): 143-8.

74. Russo ICP, Santos TMM, Busgaib BB, Osterne FJV. Um estudo comparativo sobre os efeitos da exposição à música em músicos de trios elétricos. Braz $\mathrm{J}$ Otorhinolaryngol. 1995;61(6): 477-84.

75. Brasil. Ministério do Trabalho e Emprego. Portaria 3. 214 de Julho de 1978. Normas regulamentadoras de segurança e saúde no trabalho (NR-15): atividade e operações insalubres. Brasília; 1978.

76. Alberti PW. Deficiência auditiva induzida pelo ruído. In: Lopes Filho O, Campos CA. Tratado de Otorrinolaringologia. São Paulo: Roca; 1994. p.934-49.

77. Santos JD, Ferreira MIDC. Variação dos limiares audiométricos em trabalhadores submetidos a ruído ocupacional. Arq Int Otorrinolaringol. 2008;12(2):201-9. 
78. Andrade IFC, Souza AS, Frota SMM. C. Estudo das emissões otoacústicasProduto de distorção durante a prática esportiva associada à exposição à música. Rev. CEFAC. 2009;11(4):644-66.

79. Widén SE, Holmes AE, Earlandsson SI. Reported hearing protection use in young adults from Sweden and the USA: effects of attitude and Gender. Int. J audiol. 2006;45(5):273-80.

80. Bohlin MC, Erlandsson SI. Risk behaviour and noise exposure among adolescents. Noise Health. 2007;9(36):55-63.

81. Hidecker MJC. Noise-induced hearing loss in school-age children: what do we know? Semin Hear. 2008;29(1):19-28.

82. Zocoli AMF, Morata T, Marques J, Corteletti LJ. Brazilian young adults and noise: attitudes, habits, and audiological characteristics. Int J. Audiol. 2009;48(10): 692-9.

83. Muhr P, Rosenhall U. Self-assessed auditiry symptoms, noise exposure, and measure auditory finction among healthy young Swedish men. Int. J Audiol. 2010; 49(4):317-25.

84. Zhao F, Manchaiah VK, French D, Prince SM. Music expsoure and hearing disorders: in overview. Int J Audiol. 2010;49(1):54-64.

85. Morata TC. Young people: their noise and music exposures and the risk of hearing loss. Int J Audiol. 2007;46(3):111-2. 
86. Salazar BAM, Fajardo CL, Vera CC, García PM, Solís FF. Comparación de emisiones otoacústicas producto de distorsión en individuos expuestos y no expuestos a ruido ocupacional. Cienc. Trab. 2003;5(10):24-32.

87. Seixas NS, Kujawa SG, Norton S, Sheppard L, Neitzel R, Slee A. Predictors of hearing threshold levels and distortion product otoacoustic emissions among noise exposed young adults. Occup. Environ Med. 2004;61(11):899-907.

88. Miller JAL, Marshall L, Heller LM, Hughes LM. Low-level otoacoustic emissions may predict susceptibility to noise-induced hearing loss. J. Acoust. Soc. Am.2006;120 (1):280-96.

89. Lonsbury-Martin BL, Martin GK, Telischi FF. Emissões otoacústicas na prática clínica. In: Musiek FE e Rintelmann WF. Perspectivas Atuais em Avaliação Auditiva. São Paulo: Manole, 2001, p.163-92.

90. Granjeiro RC. Estudo das emissões otoacústicas evocadas transientes e por produto de distorção em indivíduos com zumbido e limiar auditivo normal [dissertação]. Brasília (DF): Faculdade de Ciências da Saúde. Universidade de Brasília; 2005.

91. Maia JRF, Russo ICP. Estudo da audição de músicos de rock and roll. PróFono Rev. Atualiz. Cient. 2008;20(1):49-54.

92. Acentales QL, Flórez LJH, Gutiérrez JCC, Castañeda VAR, Forero CR, Palacios KM. The auditory and neuropsychological effects of school children's exposure to environmental noise in a locality in Bogotá, 2010 Rev. salud pública. 2013;15 (1):116-28. 
93. GUÍAS PARA EL RUIDO URBANO. Birgitta Berglund, Thomas Lindvall, Dietrich H Schwela [acesso em 12 de jan 2016].

94. Vogel I, Brug J, Van der Ploeg CPB, Raat H. Discotheques and the risk of hearing loss among youth: risky listening behavior and its psychosocial correlates. Health Educ Res. 2010;25(5):737-47.

95. Mohammadpoorasl HAA, Rostami F, Ahdieh Maleki A, Sahebihagh MH, Naieni KH. Pattern of Use of Earphone and Music Player Devices among Iranian Adolescents. Int J Prev Med. 2014; 5(6): 776-81.

96. Gonçalves CGO, Lacerda ABM, Zeigelboim BS, Marques JM, Luders D. Auditory thresholds among military musicians: conventional and high frequency. CoDAS 2013;25(2):181-7.

97. Berg AL, Serpanos YC. High frequency hearing sensitivity in adolescent females of a lower socioeconomic status over a period of 24 years (1985-2008). J Adol Health. 2011;48(2):203-8.

98. Juul J, Barrenäs ML, Holgers KM. Tinnitus and hearing in 7-year-old children. Arch Dis Child. 2012;97(1):28-30.

99. Kim YH, Jung HJ, Kang SI, Park KT, Choi JS, Oh SH, et al. Tinnitus in children: association with stress and trait anxiety. Laryngoscope. 2012;122(10):2279-84.

100. Knobel KAB, Lima MCMP. Os pais conhecem as queixas auditivas de seus filhos. Braz J Otorhinolaryngol. 2012;78(5):27-37. 
101. Borja ALV, Sousa BF, Ramos MM, Araújo RPC. O que os jovens adolescentes sabem sobre perdas induzidas pelo excesso de ruído? Rev. Ciênc. Méd. Biol. 2002;1(1):86-98. 
ANEXOS

ANEXO I

\section{PARECER CONSUBSTANCIADO DO COMITÊ DE ÉTICA}

FACULDADE DE MEDICINA DA

UNIVERSIDADE DE BRASÍLIA - Plotoformo

UNB

\section{PARECER CONSUBSTANCIADO DO CEP}

\section{DADOS DO PROJETO DE PESQUISA}

Título da Pesquisa: Associação da prevalência de lesão das células ciliadas externas em adolescentes do Distrito Federal: Um estudo de caso-controle.

Pesquisador: Valéria Gomes da Silva

Área Temática:

Versão: 1

CAAE: 12659213.0 .0000 .5558

Instituição Proponente: Faculdade de Medicina da Universidade de Brasília - UNB

Patrocinador Principal: Financiamento Próprio

DADOS DO PARECER

Número do Parecer: 659.058

Data da Relatoria: $30 / 04 / 2014$

Apresentação do Projeto:

Trata-se de estudo do tipo caso-controle, com amostra de conveniência com um total de 96 sujeitos, com idades entre 13 e 18 anos, sem queixas de doenças otológicas, sem uso de aparelhos de amplificação sonora individual, sem uso de medicamentos ototóxicos e sem alteração de ouvido/orelha médio/a. Os exames serão analisados de acordo com o critério "passa/falha", nos parâmetros da amplitude e da relação sinal/ruído. Simultaneamente, os indivíduos serão investigados sobre o uso de fones de ouvido e hábitos auditivos.

Objetivo da Pesquisa:

Verificar a associação das alterações das células ciliadas externas com a exposição à música amplificada em uma amostra de adolescentes do Distrito Federal e medir a prevalência de alteração no exame de EOAT em pelo menos 1 (uma) orelha da população de adolescentes do Distrito Federal.

Avaliação dos Riscos e Benefícios:

Não há riscos. Quanto aos beneficios, o estudo utitizará a análise de EOA por estímulo transiente, buscando verificar se as alterações das células cocleares estão relacionadas com a prática de ouvir e/ou se expor a música amplifica. Os participantes serão beneficiados com os exames, sem qualquer ônus, que servirão de triagem auditiva. Receberão os resultados e orientações

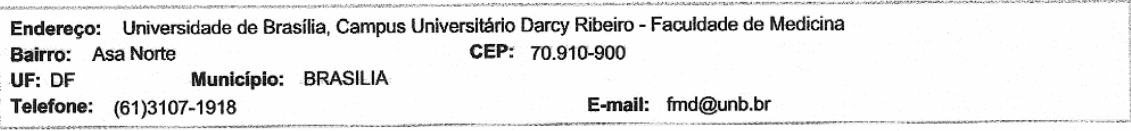




\section{FACULDADE DE MEDICINA DA UNIVERSIDADE DE BRASÍLIA - UNB}

Continuação do Parecer: 659.05

pertinentes da pesquisadora e caso seja detectada alguma alteração, serão encaminhados para assistência médica (otorrinolaringologista). Por fim, o estudo poderá alertar e orientar os jovens sobre a perda auditiva precocemente.

Comentários e Considerações sobre a Pesquisa:

A pesquisa tem relevância para as políticas de saúde pública, não apresenta riscos e será custeada pela pesquisadora, que é Fonaudióloga.

Considerações sobre os Termos de apresentação obrigatória:

O TCLE precisa contemplar o consentimento do/s responsável pelo sujeito, se menos de 18 anos. Há previsão desse requisito, que, entretanto, não foi contemplado no formulário enviado.

Recomendações:

Ajuste no TCLE para contemplar, também, o consentimento do responsável pelo sujeito, quando menor de 18 anos.

Conclusões ou Pendências e Lista de Inadequações:

Não há pendências.

Situação do Parecer:

Aprovado

Necessita Apreciação da CONEP:

Não

Considerações Finais a critério do CEP:

O presente projeto corresponde a um estudo do tipo caso-controle, com amostra de conveniência com um total de 96 sujeitos, com idades entre 13 e 18 anos, sem queixas de doenças otológicas, sem uso de aparelhos de amplificação sonora individual, sem uso de medicamentos ototóxicos e sem alteração de ouvido/orelha médio/a. Os exames serão analisados de acordo com o critério "passa/falha", nos parâmetros da amplitude e da relação sinal/ruído. Simultaneamente, os indivíduos serão investigados sobre o uso de fones de ouvido e hábitos auditivos. A pesquisa tem relevância para as políticas de saúde pública e não apresenta risco.

Após discussão neste colegiado optou-se por sua aprovação sem pendência e a recomendação para o ajuste do TCLE.

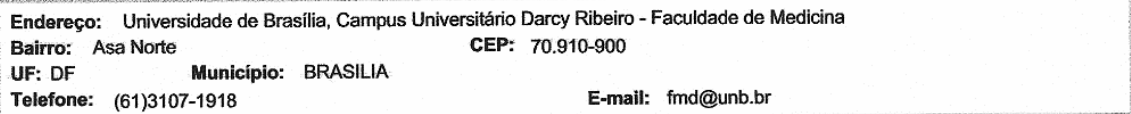


FACULDADE DE MEDICINA DA UNIVERSIDADE DE BRASÍLIA UNB

Continuaçăo do Parecer: 659.058

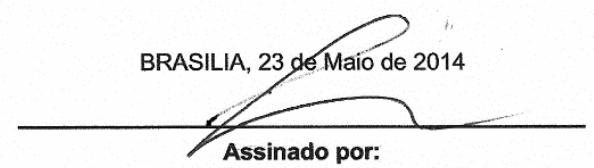

Florêncio Figueiredo Cavalcanti Neto (Coordenador)

Endereço: Universidade de Brasilla Campus Universitário Darcy Ribeiro - Faculdade de Medicina

Bairro: Asa Norte

CEP: $70.910-900$

UF: DF Município: BRASILIA

Telefone: (61)3107-1918 E-mail: fmd@unb.br 
ANEXO II

LAUDO DE MEDIÇÃO DE NPS DAS ESCOLAS

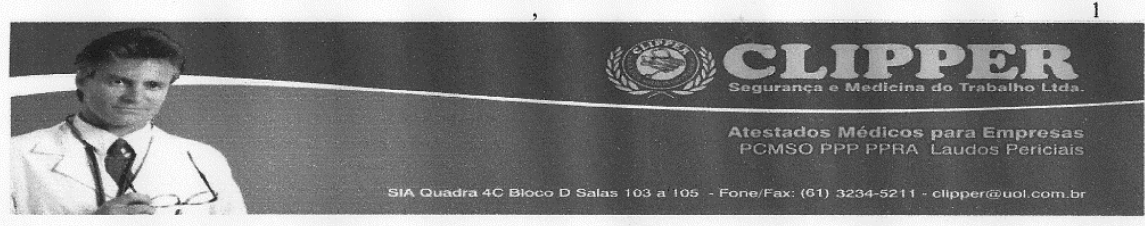

Medição de Níveis de pressão sonora em ambiente laboral

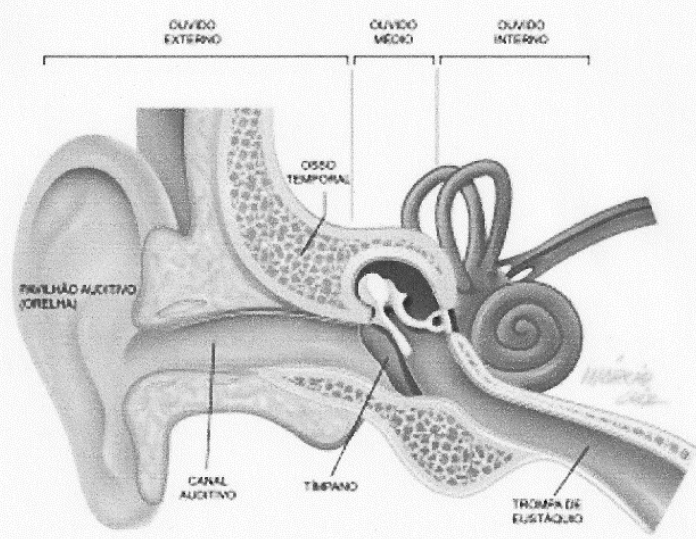

CUPPER SEQURANGA E AEDIEIMA DO TRABALHO ITD

S.A. Sul Quadra 4 \& Bloco D Wo.72 Salas 104/105 GEP 71.200-045 Fax/Fone [61] 3234.5211 3233.9537 - Brasilla BF Elipper@uol.cem.br

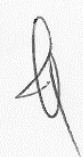




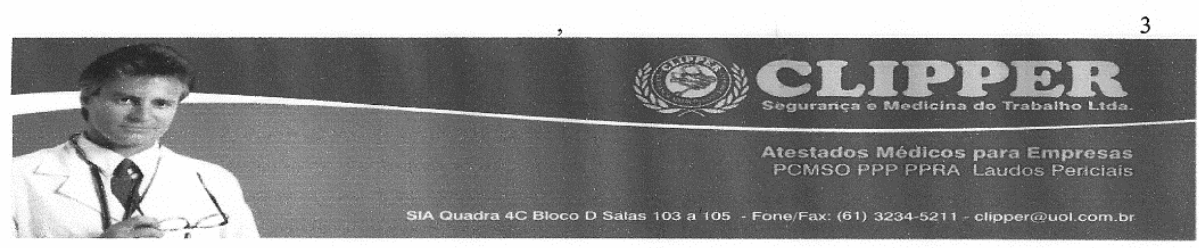

\section{Características da Edificação:}

1. Trata-se de área totalmente cercada com acesso através de portões.

2. Trata-se de uma instituição educacional toda edificada em alvenaria.

3. O terreno em questão faz limites frontais com a rua pavimentada.

4. O terreno em questão faz limites laterais com 2 vizinhos.

5. No fundo do terreno não há vizinhos diretos.

\section{Condiçōes do local durante levantamento dos níveis sonoros:}

1. Realizado em 12 de agosto de 2013.

2. No período da manhã

3. Em dia normal de trabalho

4. Temperatura média do local: $24,2^{\circ}$. C

5. Umidade Relativa do Ar: $63 \%$

6. Velocidade do Ar no centro da edificação: $3,8 \mathrm{~m} / \mathrm{s}$

7. Especificação de local= Sala de Aulas

8. Em um dia claro sem barulho de chuvas nos telhados, nem trovoadas 


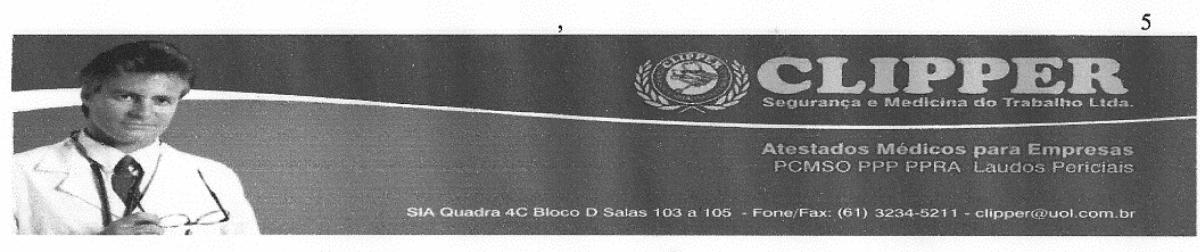

\section{Especificaçāo do local mensurado}

1. Sala de Aula desta Instituição de Ensino.

2. Este local mede aproximadamente $9,00 \mathrm{~m} \times 6,00 \mathrm{~m}$

3. Tem formação aproximadamente retangular.

4. Possui 01 porta de acesso com largura de $0,90 \mathrm{~m}$

5. Possui paredes comuns emassadas e pintadas com tinta imobiliária comum.

6. Possui janelas tipo blindex modelo basculantes

7. Possui várias cadeiras escolares em muito bom estado de conservação, sendo essas confeccionadas em ferro e madeira.

8. Piso liso padrão comercial.

9. Ventilação natural e também artificial via conjunto de Lâmpadas;

10. Teto de concreto com luminárias largas 


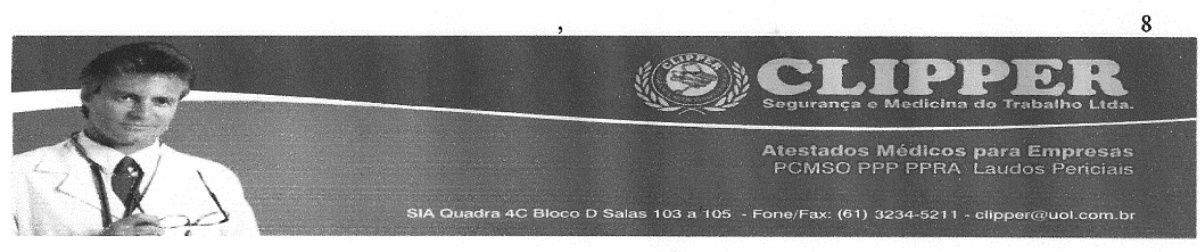

Legislação:

Portaria No. 3.214 Norma Regulamentadora NR 15 Anexo I, baixada pelo Ministério do Trabalho e Emprego

TABELA DE LIMITES DE TOLERÂNCIA PARA RUÍDO CONTÍNUO OU INTERMITENTE

\begin{tabular}{|c|l|}
\hline $\begin{array}{c}\text { Nível de Ruído dB } \\
\text { (A) }\end{array}$ & Máxima exposição diária Permissível \\
\hline & \\
\hline 85 & 8 horas \\
\hline 86 & 7 horas \\
\hline 87 & 6 horas \\
\hline 88 & 5 horas \\
\hline 89 & 4 horas e trinta minutos \\
\hline 90 & 4 horas \\
\hline 91 & 3 horas e trinta minutos \\
\hline 92 & 3 horas \\
\hline 93 & 2 horas e quarenta minutos \\
\hline 94 & 2 horas e quinze minutos \\
\hline 95 & 2 horas \\
\hline 96 & 1 hora e quarenta e cinco minutos \\
\hline 98 & 1 hora e quinze minutos \\
\hline 100 & 1 hora \\
\hline 102 & 45 minutos \\
\hline 104 & 35 minutos \\
\hline 105 & 30 minutos \\
\hline 106 & 25 minutos \\
\hline 108 & 20 minutos \\
\hline 110 & 15 minutos \\
\hline 112 & 10 minutos \\
\hline 114 & 8 minutos \\
\hline 115 & 7 minutos \\
\hline & \\
\hline
\end{tabular}

GLIPER SEQURAMCA E MEDIRIM DO TRABALHO LTMA.

S.IA. Sul Quadra 4 G Bloce D w0.12 Salas 104/105 GEP 7.200-045 Fax/Fone [61 3234.5211 3233.9537 - Brasilla DF Glipper@uel.sem.br 


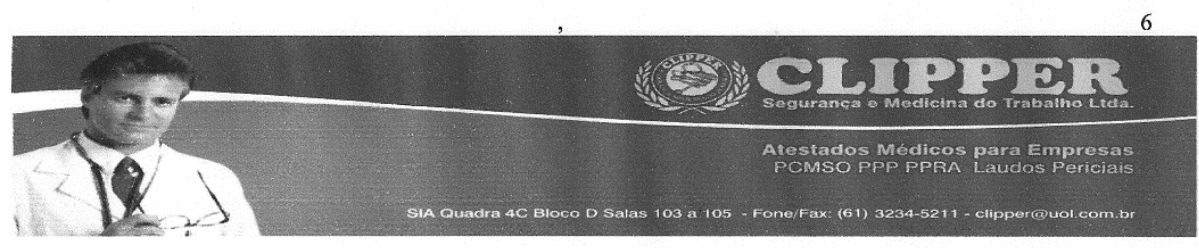

\section{Observações}

1. Foram feitas 3 sessões com 5 medições neste local: sendo uma em cada extremidade da sala de aulas e uma no centro.

1. Medidor colocado na altura do ouvido dos trabalhadores.

2. Medições em dia normal.

3. Foi evitado a interferência do vento no microfone do medidor, para isso foi utilizado um dispositivo denominado "windscreen" que evita o "sopro" sobre o microfone.

4. Foram evitadas superfícies refletoras, que não sejam comuns ao ambiente. Para evitar que o corpo da pessoa que faz a medição não interfira nas medidas;

5. O principal causador de erros nas medições de ruído é o Ruído de Fundo. Trata-se do ruído do ambiente, que não faz parte do ruído daquele local. Para comprovar a sua influência, mede-se o nível de ruído de uma máquina em funcionamento e, em seguida, desligada. No primeiro caso é medido o ruído total (ruído da máquina + ruído de fundo), e no segundo caso apenas o ruído de fundo. Se a diferença do nível for menor que $3 \mathrm{~dB}$, indica um ruído de fundo. Se a diferença no nível for menor que $3 \mathrm{~dB}$, indica um ruído de fundo bastante intenso, que deve ser levado em consideração nas medições. Neste caso especifico, foram feitas medições somente com os equipamentos desligados, visto que são utilizados esporadicamente.

6. Sala de Aula com porta de acesso fechada.

7. Sala de Aula com janelas fechadas .

8. Sem a presença de pessoas no horário das medições. 


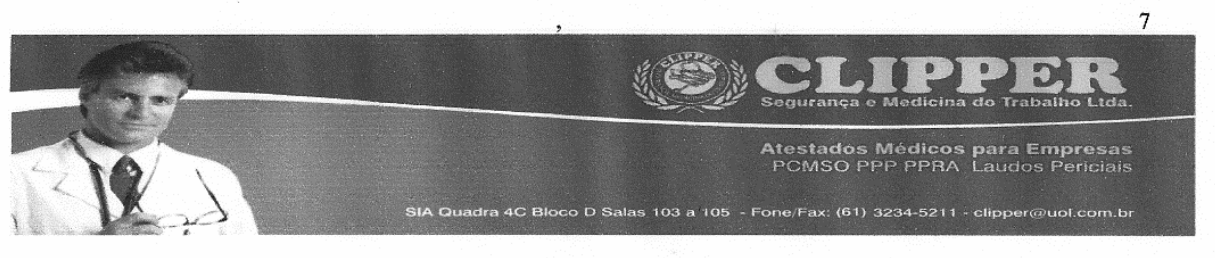

\begin{tabular}{|c|c|c|c|}
\hline $\begin{array}{c}\text { No. de } \\
\text { marcação }\end{array}$ & LOCAL DE MEDIÇĀO & $\begin{array}{c}\text { MEDIÇĀO } \\
\text { EM dB }\end{array}$ & Obs \\
\hline & & & \\
\hline & PRIMEIRA MEDIÇÃO & & \\
\hline 1 & Centro da Sala & 40,20 & $(*)$ \\
\hline 2 & Próximo a um dos cantos da Sala (canto A) & 40,20 & $(*)$ \\
\hline 3 & Próximo a um dos cantos da Sala (canto B) & 40,00 & $(*)$ \\
\hline 4 & Próximo a um dos cantos da Sala (canto C) & 40,10 & $(*)$ \\
\hline \multirow[t]{2}{*}{5} & Próximo a um dos cantos da Sala (Canto D) & 40,10 & $(*)$ \\
\hline & SEGUNDA MEDIÇÃO $\quad\left({ }^{* *}\right)$ & & \\
\hline 6 & Centro da Sala & 39,70 & $(*)$ \\
\hline 7 & Próximo a um dos cantos da Sala (canto A) & 39,70 & $(*)$ \\
\hline 8 & Próximo a um dos cantos da Sala (canto B) & 39,60 & $(*)$ \\
\hline 9 & Próximo a um dos cantos da Sala (canto C) & 39,70 & $(*)$ \\
\hline \multirow[t]{2}{*}{10} & Próximo a um dos cantos da Sala (Canto D) & 39,70 & $(*)$ \\
\hline & TERCEIRA MEDIÇÃO ( $\left.{ }^{* * *}\right)$ & & \\
\hline 11 & Centro da Sala & 39,10 & $(*)$ \\
\hline 12 & Próximo a um dos cantos da Sala (canto A) & 39,10 & $(*)$ \\
\hline 13 & Próximo a um dos cantos da Sala (canto B) & 39,00 & $(*)$ \\
\hline 14 & Próximo a um dos cantos da Sala (canto C) & 39,00 & $(*)$ \\
\hline 15 & Próximo a um dos cantos da Sala (Canto D) & 39,10 & $(*)$ \\
\hline
\end{tabular}

$\left({ }^{*}\right)$ - Dados sobre ruídos coletados em local normal de trabalho e ao nível do ouvido humano.

(**) - Realizada 40 minutos após a primeira medição

${ }^{(* * *)}$ - Realizada 40 minutos após a segunda medição 


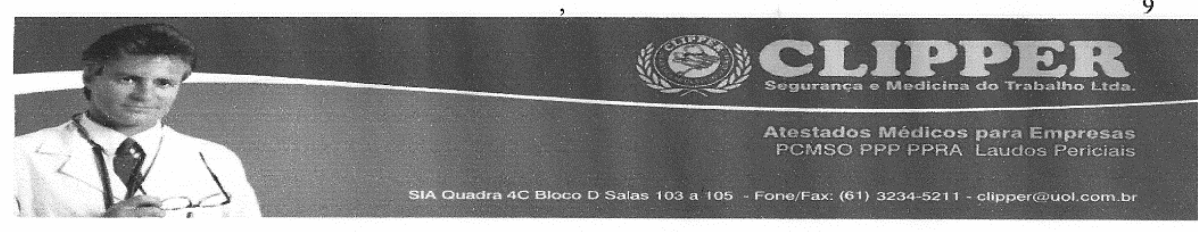

\section{Comentório}

Níveis de ruído foram observados em dia normal e habitual de trabalho.

Observação: Os níveis de ruído observados nestes ambientes de trabalho estão dentro dos LIMITES DE TOLERÂNCIA PARA RUIDOO CONTINNUO OU INTERMITENTE segundo o anexo No. 01 da Norma Regulamentadora NR 15 da Portaria No. 3.214, baixada pelo Ministério do Trabalho (MTb). Interna e externamente.

OBS: Não observados ruídos de impacto significativos ou relevantes neste ambiente laboral.

\section{Realizado por:}

João Batista Avelino Filho

Técnico de Segurança do Trabalho

Registro no Ministério do Trabalho No. 13/0005.3

Higienista Ocupacional

Registro na Associação Brasileira de Higienistas Ocupacionais - ABHO 302/DF

Este documento é composto de 9 páginqs numeradas sequencialmente.

Brasília-DF, 12 de agosto de 2013

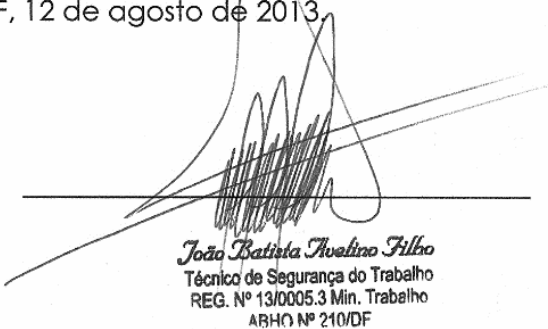

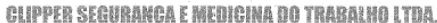

S.IA. Sul Quadra 4 \& Bleco D ho.72 Salas 104/105 GEP 71.200-045 Fay/Fane [61] 3234.5211 3233.9537 - Brasilia DF clipner@uel.com.hr 


\section{ANEXO III}

\section{TEXTO INFORMATIVO}

\section{Você sabia?}

Ficar exposto por muito tempo a certos tipos de ruídos pode causar perda de audição!

A PAIR - Perda Auditiva Induzida por Ruído é um tipo de perda auditiva decorrente da exposição prolongada a sons de alta intensidade. Ela ocorre muito lentamente, ao longo do tempo, danificando os microcílios (células ciliadas) localizados na cóclea e, uma vez danificados, eles não podem ser mais recuperados, ou seja, trata-se de uma perda auditiva irreversível. Em determinados casos, uma única exposição a sons intensos é capaz de danificar a audição.

A audição é fundamental à vida, pois é a base da comunicação humana. O ouvido, órgão responsável pela audição, é dividido em três partes: ouvido externo, médio e interno. Dessas partes, o ouvido interno é o mais importante, pois é onde se localiza a cóclea. Nela, está localizada uma estrutura essencial a audição, o órgão de corti, que abriga as células ciliadas. Portanto, a exposição contínua a ruídos altos de $90 \mathrm{~dB}$ ou mais já pode causar lesões no ouvido interno resultando em uma perda auditiva.

Se você trabalha e/ou convive em ambientes ruidosos ou mesmo tem o habito de se expor com frequência a sons de alta intensidade, fique atento. Buzinas, máquinas, shows, boates, músicas em volumes altos e até mesmo os MP3 atingem intensidades sonoras muito elevadas, que podem estar comprometendo sua audição.

Existem sinais que indicam que você está sendo exposto a níveis excessivos de ruído. Veja alguns:

* Ter de gritar para ser ouvido.

* Ouvir uma campainha ou barulho no ouvido (zumbido).

* Perder audição, ainda que temporariamente, após exposição a som intenso.

Conheça os principais níveis sonoros:

\begin{tabular}{|c|l|}
\hline NíVEL EM DECIBÉIS (DB) & \multicolumn{1}{c|}{ SONS } \\
\hline 30 & Sussurro \\
\hline 50 & Chuva, escritório tranquilo, geladeira \\
\hline 60 & Conversa, máquina de lavar louças \\
\hline 70 & Trânsito, aspirador de pó, restaurantes \\
\hline 80 & Alarme de relógio, metrô, apito de indústria \\
\hline 90 & Barbeador elétrico, cortador de grama \\
\hline 100 & Caminhão, serra elétrica, aparelhos de som \\
\hline 110 & Show de rock, boate, motoserra \\
\hline 120 & Turbina de avião, danceterias/boates, MP3 \\
\hline 140 & Tiro, alarmes de ataque aéreo \\
\hline 180 & Decolagem de foguete \\
\hline
\end{tabular}

'Sons de 85dB acima por tempo prolongado levam à perda de audição. 


\section{APÊNDICES}

\section{APÊNDICE A}

\section{TERMO DE CONSENTIMENTO LIVRE E ESCLARECIDO}

Universidade de Brasília (UnB)

De acordo com a Resolução n. 196/96, de 10 de outubro de 1996, do Conselho de Saúde, esta pesquisa, intitulada "Lesão de células cocleares em adolescentes do Distrito Federal e a exposição à música amplificada", será realizada pela pesquisadora Fonoaudióloga Valéria Gomes da Silva, sob orientação do Prof. Dr. Carlos Augusto Costa Pires de Oliveira.

Esta pesquisa, realizada em nível de Doutorado no Programa de Pós-Graduação da Faculdade de Medicina da Universidade de Brasília (UnB), tem por finalidade investigar os hábitos auditivos e avaliar a audição de jovens e adolescentes. Este trabalho, que será feito na própria escola, será realizado por meio da aplicação de um questionário sobre os hábitos auditivos e de exames de audiometria Imitanciometria e Emissões Otoacústicas Evocadas (EOA), o qual é indolor, não é invasivo e não oferece nenhum risco à saúde ou desconforto ao participante.

A participação na pesquisa é voluntária, não havendo pagamentos. Caso decida não participar, ou desista por qualquer motivo, não haverá nenhum prejuízo. Será garantido o sigilo das informações obtidas e, na publicação dos resultados, será mantido o anonimato dos participantes.

A pesquisadora estará à disposição para prestar qualquer esclarecimento que se fizer necessário e ficará responsável pela guarda deste documento e de todas as informações obtidas.

Diante do exposto, solicito sua valiosa contribuição para participar da pesquisa, conforme os procedimentos citados.

OBS: AOS MENORES DE 18 ANOS (Obrigatória assinatura do pai ou responsável legal).

$\mathrm{Eu}$, abaixo assinado, declaro ter lido o presente documento, e de forma livre e esclarecida, manifesto meu consentimento e autorizo a participação do aluno(a) no presente estudo, conforme os procedimentos informados acima.

Brasília, de de 2014 . 


\section{APÊNDICE B}

\section{ANAMNESE - PROTOCOLO DE SELEÇÃO}

Nome:

Turma: Idade:

Gênero: $\quad$ ( ) M ～～～F

\section{ANTECEDENTES GERAIS:}

Já esteve internado tomando antibióticos?

$\operatorname{sim}()$

não ( )

Fez tratamento quimioterápico?

$\operatorname{sim}()$

não ( )

Sente tonturas com frequência?

$\operatorname{sim}()$

não ( )

Fez uso recente de medicamentos?

$\operatorname{sim}()$

não ( )

Qual?

\section{ANTECEDENTES OTOLÓGICOS:}

Já foi submetido a cirurgia no ouvido?

$\operatorname{sim}()$

não ( )

Alguma vez já saiu pus ou sangue do ouvido?

$\operatorname{sim}()$

não ( )

Já foi diagnosticado ou nasceu com doença

no ouvido?

Sente dor de ouvido?

Sente pressão ou ouvido tampado?

Sente zumbido ou barulho no ouvido?

$\operatorname{sim}()$

não ( )

$\operatorname{sim}()$

não ( )

$\operatorname{sim}()$

não ( )

$\operatorname{sim}()$

não ( )

Possui perda auditiva?

$\operatorname{sim}()$

não ( )

\section{HÁBITOS AUDITIVOS:}

Ouve música usando fones de ouvido?

$\operatorname{sim}()$

não ( )

Frequenta lugares com música amplificada,

como boates, shows etc.?

$\operatorname{sim}()$

não ( )

Obs.: 


\section{APÊNDICE C}

\section{QUESTIONÁRIO}

Levantamento sobre hábitos auditivos de jovens e adolescentes em relação ao uso de fones de ouvido e exposição à música amplificada.

Nome:

Série/Turma:

Idade:

Sexo: ( )M ( )F

\section{RESPONDA:}

1- Você tem o hábito de usar com frequência fones de ouvido para ouvir música?
A-( ) sim
B-( ) não

2 - Costuma frequentar ambientes com som muito alto como: shows, concertos, boates, festas, academias ou outros semelhantes?
A-( ) sim
B-( ) não

Se você assinalou "SIM" às essas primeiras questões, responda as demais. Se você assinalou "NÃO", entregue o questionário. Obrigada!

3- O som dos fones que você usa, encobre o barulho externo?
A-( ) $\operatorname{sim}$
B-( ) não

4- A quanto tempo você tem esse hábito de ouvir música usando os fones?
A-( ) há mais de 1 ano?
B-( ) há menos de 1 ano?

5- Com que frequência costuma ouvir música usando os fones de ouvido?

A-( ) todos os dias? B-( ) menos de 3 dias $\mathrm{p} /$ semana?

6- Em média, qual o tempo diário que costuma ouvir?

$\mathrm{A}-(\mathrm{)})$ mais de $2 \mathrm{~h} \mathrm{p} / \mathrm{dia} \quad \mathrm{B}-(\mathrm{l})$ menos de $1 \mathrm{~h} \mathrm{p} / \mathrm{dia}$ ?

7- Quanto aos lugares que você frequenta, à quanto tempo começou a frequentar esses ambientes?

A-( ) há mais de 1 ano? B-( ) há menos de 1 ano?

8- Com que frequência você vai a esses lugares?

A-( ) mais de 1x por mês $\quad$ B-( ) 1x por mês 